\title{
Creación y caída en los libros XI-XIV de «La Ciudad de Dios»
}

La dialéctica de los dos amores y la oposición entre las dos ciudades son temas abundantemente tratados por Agustín antes de la composición de su gran obra La Ciudad de Dios ${ }^{1}$. Esto significa que el saqueo de Roma por Alarico el 24 de agosto del 410 no tiene una importancia tan grande como se le ha querido dar a la hora de explicar los motivos y los condicionamientos de la composición de esta obra. El saqueo de Roma debe ser considerado más bien como una ocasión providencial que movió a San Agustín a poner por escrito de una manera sistemática lo que ya desde tiempo bullía en su espíritu ${ }^{2}$.

Pero si este acontecimiento histórico no es de importancia capital para la comprensión de las ideas básicas de La Ciudad de Dios, es sin embargo esencial a la hora de explicarnos las motivaciones y las circunstancias históricas de los diez primeros libros. En efecto, después del saqueo de Roma por Alarico, muchos paganos acusaron a los cristianos de haber sido la causa de tal desgracia, añadiendo que con su desprecio de los dioses del Imperio habían despertado la cólera de éstos, que en castigo habían dejado a Roma desamparada en manos de los bárbaros.

San Agustín, dolido tanto por la destrucción de Roma como por estas voces acusadoras, emprende la tarea de la composición de La Ciudad de Dios, para refutar las acusaciones de los gentiles y para explicar la finalidad de los reinos e imperios terrenos dentro de los planes de la Providencia divina.

1 Cf. A. Lauras - H. Rondet, Le thème des deux cités dans l'oeuvre de Saint Augustin, en "Etudes Augustliniennes" (Paris 1953) 97-160; igualmente ef. A. Lauras, Deux cités, Jérusalem et Babylone, "La Ciudad de Dios", núm. extr., I, vol. 167, 117-152.

2 Cf. J. MoRÁN, Introducción general a La Ciudad de Dios, BAC 171, Madrid 1964, p. XIV-XV. 
Después de mostrar en el libro primero que las tribulaciones de la invasión de Roma fueron comunes a los cristianos y a los paganos, y de explicar por qué la Providencia permite que estos males recaigan también sobre los buenos, San Agustín demuestra que el Imperio Romano no debe su prosperidad a los dioses, que, al contrario, con sus instigaciones a la inmoralidad fueron causa de su ruina (libros segundo y tercero), sino a la Providencia del único Dios, del cual depende no sólo la felicidad eterna, sino también la felicidad terrena (libros cuarto y quinto).

Partiendo de este punto San Agustín emprende su ataque contra los innumerables dioses del Imperio; si éstos no fueron capaces de mantener la prosperidad del Imperio Romano y de dar la felicidad de este mundo, ¿cómo podrán dar la felicidad de la vida eterna? Por lo tanto no son verdaderos dioses, y sólo queda como único Dios el Dios de los cristianos (libros sexto y séptimo).

Del politeísmo popular San Agustín pasa a la filosofía. Tampoco ésta, por muy elevada que sea, puede ser causa ni dadora de la vida eterna (libro octavo). Esta filosofía, a su vez, ha desarrollado una amplia gama de distinciones entre dioses buenos y malos, ángeles y demonios, demiurgos, etc. Es evidente que los dioses malos o demonios no pueden conseguirnos la beatitud eterna (libro octavo); pero tampoco los demonios buenos, si es que existen, cosa que San Agustín refuta, podrán ser mediadores en orden a conseguir la vida beata. Cristo es el único mediador que tenemos para alcanzar la eterna felicidad (libro nono).

El último libro de esta primera parte lo dedica San Agustín a mostrar que los ángeles y santos, llamados dioses por la Escritura, no son objeto del culto de latría, debido únicamente a Dios, sino sólo de una veneración especial por habernos precedido ya en el descanso eterno.

Demostrada así la inutilidad del paganismo y de la filosofía en orden a conseguir la salvación, y demostrado que sólo existe una vía de salvación, Cristo, Agustín pasa a explicar el nacimiento y desarrollo histórico de las dos ciudades, la ciudad terrena, formada por los hombres carnales y por los ángeles soberbios, y la ciudad de Dios, en la cual se reúnen los que aceptan a Cristo como el camino de su felicidad imperdurable. 
Llegamos de este modo a los libros XI-XIV, objeto de este estudio, en los cuales se expone el nacimiento de estas dos ciudades, la creación como origen de la ciudad celeste y el pecado de los ángeles y de los hombres, punto de partida de la ciudad terrena.

Pero antes de comenzar el análisis de estos cuatro libros debemos situarlos cronológicamente dentro de la obra agustiniana, principalmente con respecto a los otros tratados en los que el Santo habla de la creación y del primer pecado. Estos tratados se pueden reducir a las obras de exégesis e interpretación del Génesis, en las cuales el problema surge inevitablemente al estudiar los primeros capítulos de este libro. Tres veces inicia San Agustín esta tarea, con diversas características y éxito diferente en cada caso.

El primero de ellos es el De Genesi contra Manichaeos, que fue escrito poco después de su conversión y en los primeros tiempos de su estancia en Africa, o sea, entre los años 388 y $389^{3}$. Sigue el De Genesi ad litteram, imperfectus liber, que debe haber sido escrito alrededor del año 393, como se deduce de las Retractationes, en las cuales aparece revisado inmediatamente después del opúsculo o sermón De fide vel symbolo, que fue predicado por el Santo en el concilio de Hipona de ese año.

El año 401, al parecer ${ }^{4}$, comienza una nueva exposición literal del Génesis, el tratado De Genesi ad litteram, libri duodecim, cuya composición se prolongará hasta el año $414^{5}$.

En los tres últimos libros de las Confesiones, San Agustín hace una exposición alegórica del primer capítulo del Génesis. La datación de estos libros es difícil de determinar, pero, en todo caso, no deben ser posteriores al año 400 ó $401^{6}$.

3 El mismo Agustín nos proporciona esta información en el De Genesi ad Litteram VIII, 2, 5, PL 34, 373: "Nam et ego contra Manichaeos... duos coniscripsi libros recenti tempore conversionis meae". Del mismo modo en las Retractationes I, 10, PL 32, 599: "Iam vero in Africa constitutus, sicripsi duos libros De Genesi contra Manichaeos".

4 "Hos sane libros posterius coepi, sed' prius terminavi quam De Trinitate" (Retract. II, 24, PL 32, 640). El tratado sobre la Trinidad fue comenzado el año 400 .

5 Eil año 412, escribiendo a Marceliano, San Agustín dice: "Periculosissimarum quaestionum libros De Genesi... et De Trinitate diutius teneo quam vultis et fertis" (Epist. 143, 4, PL 33, 587). El año 414 había terminado la redacción dell libro iduodécimo, pero todavía no había publicado el tratado. Cff. Episit. 159, 2, PL 33, 699 .

6 La dificultad proviene del hecho que algrunois críticos consideran estos tres libros un poco posteriores al restio de las Confesiones, mientras que otros creen 
Los libros XI-XIV de La Ciudad de Dios, a su vez fueron escritos entre el año 416 y el 420 . El libro undécimo es mencionado por Orosio en el prefacio de su Historia contra los paganos, obra que data del 417, y en el libro Contra adversarium Legis et Prophetarum $(I, 14,18)$ de Agustín, compuesto hacia el año 420, se da ya como escrito el libro XIV de La Ciudad de Dios.

Tenemos pues que los libros XI-XIV de La Ciudad de Dios representan el último estadio en la especulación agustiniana sobre la creación y la caída del primer hombre, la fijación de su pensamiento definitivo. Por ahora tenemos bastante con esta constatación simplemente cronológica; tal vez en otra ocasión podremos hacer un estudio sobre la evolución del Santo en esta materia, poniendo en relación estos libros de La Ciudad de Dios con los otros tratados citados anteriormente.

Finalmente es preciso constatar el carácter parcial de estos libros con respecto a la doctrina de la creación y del pecado; es decir, estos temas no son tratados en sí mismos, sino en función de la problemática de los dos amores y de las dos ciudades, por lo cual no podemos esperar un tratado completo y sistemático de todas las cuestiones implicadas en la creación y la caída de los primeros padres. Sin embargo, de estos cuatro libros de La Ciudad de Dios se puede sacar una visión general bastante completa del pensamiento agustiniano sobre estos problemas, a lo cual ayuda el mismo estilo asistemático de San Agustín, que gusta de disquisiciones y discusiones sobre temas más o menos marginales al tema que va desarrollando.

\section{LA CREACIÓN, OBRA DE DIOS.}

Comenzamos, pues, después de estas consideraciones introductorias con el estudio de estos cuatro libros, analizando el pensamiento agustiniano sobre la creación.

Naturalmente, para San Agustín, todo lo existente es obra de Dios, como aparece claramente en las Sagradas Escrituras, autoridad máxima en estas cuestiones ${ }^{7}$ :

que forman parte del esquema y de la redacción originales. En este último caso podrían colocarse entre ell año 396 y el 397.

7 "Hic prius per Prophetas, deinde per se ipsum, postea per Apostolos, 
«Quod autem Deus mundum fecerit, nulli tutius credimus quam ipsi Deo. Ubi enim audivimus? Nusquam interim nos melius quam in Scripturis sanctis, ubi dixit propheta eius, In principio fecit Deus caelum et terram» 8 .

Que la creación es obra de Dios nos es conocido, pues, primeramente por el testimonio de las Escrituras. Pero Agustín se sirve también de la razón para probar que el mundo necesita un supremo hacedor:

«Magnum est et admodum rarum universam creaturam corpoream et incorpoream consideratam compertamque mutabilem intentione mentis excedere, atque ad incommutabilem Dei substantiam pervenire, et illic discere ex ipso, quod cunctam naturam quae non est quod ipse, non fecit nisi ipse» 9.

En estas palabras está compendiado el argumento que San Agustín usa en el De libero arbitrio para demostrar la existencia de Dios. La mutabilidad de las creaturas nos obliga a sobrepasarlas y así llegamos a la existencia de un supremo inmutable. Pero en este caso San Agustín no se detiene en este punto, sino que dando un paso hacia adelante, proclama que sólo Dios, el único ser inmutable, puede haber creado todo lo que no es $\mathrm{El}$ mismo. Al movimiento ascendente de la razón, que de las creaturas sube hasta Dios, sigue otro descendente, que partiendo de Dios llega hasta las creaturas, que de este modo nos aparecen como la obra de su potencia creadora:

En este texto San Agustín dice que la creación nos es conocida a partir de la consideración de la inmutabilidad divina: «Et illic discere ex ipso, quod cunctam naturam quae non est quod ipse, non fecit nisi ipse». Pero también podemos llegar a la misma conclusión partiendo de las mismas creaturas:

«Exceptis enim propheticis vocibus, mundus ipse ordinatissima sua mutabilitate et mobilitate et visibilium omnium pulcherrima specie quodammodo tacitus et factum se esse, et nonnisi a Deo ineffabiliter atque invisibiliter magno et ineffabiliter atque invisibiliter pulchro fieri se potuisse proclamat» ${ }^{10}$.

quantum satis esse iudicavit, locutus, etiam Scripturam condidit, quae canonica nominatur, eminentissimae auctoritatis, cui fidem habemus de his rebus quas ignorare non expedit, nec per nosmetipsos nosse idonei sumus" (De Civ. Dei $\mathrm{XI}, 3, \mathrm{PL} 41,318$ ).

8 Ibiid. XI, 4, 1, PL 41, 319 .

9. Iibid. XI, 2, PL 41, 317.

10. Ibbid. XI, 4, 2, PL 41, 319 . 
La belleza, la movilidad, el orden del mundo son como un grito silencioso que proclama su creaturalidad y su dependencia de Dios, como lo dice Agustín en este texto, eco de aquel famoso pasaje de las Confesiones en el que interpelando a todas las cosas, recibe de ellas siempre la misma respuesta: No somos tu Dios, El es quien nos ha hecho ${ }^{11}$.

La creación se distingue de la generación. Lo generado de Dios, bien simple e inmutable, es igualmente simple e inmutable, es decir, el Verbo divino, segunda Persona de la Trinidad. Las cosas, por el contrario, han sido creadas y llevan en sí la marca de su creaturalidad, la mutabilidad y el cambio ${ }^{12}$.

Todas las cosas han sido creadas por Dios y no hay nada que quede excluído de su acción creadora. Es lo que dice San Agustín en polémica contra los maniqueos a propósito del origen de los ángeles malos ${ }^{13}$, y lo que repite en contra de una opinión que sostenía que las aguas primordiales no habían sido creadas por Dios ${ }^{14}$. Del mismo modo, en contra de los platónicos, que defendían que los cuerpos eran obra de los ángeles o dioses inferiores, San Agustín proclama la universalidad de la obra creadora de Dios ${ }^{15}$. Todo ha sido creado por Dios, materia y espíritu, cuerpo y alma, los cielos y la tierra, todo el universo que nos rodea.

11 Conf. X, 6, 9, PL 32, 783.

12 "Est itaque bonum solum simplex, et ob hoc solum incommutabile, quod est Deus. Ab hoc bono creata sunt omnia bona, sed non simplicia, et ob hoc mutabilia. Creata sane, inquam, id est, facta, non genita. Quod enim de simplici bono genitum est, pariter simplex est, et hoc est quod illud de quo genitum est" (De Civ. Dei XI, 10, 1, PL 41, 325). "Dicimus itaque incommutabile bonum non esse, nisi unum verum beatum Deum: ea vero quae fecit, bona quidem esse, quad ab illo; verumtamen mutabilia, quold non de illo, sed de nihilo facta sunt" (Ibid. XII, 1, 3, PL 41, 349).

13 "Initium ergo eius figmentum est Domini: non enim est ulla natura etiam in extremis infimisque bestioilis, quam non ille constituit, a quo est omnis modus, omnis species, omnis ordo, sine quibus nihil rerum inveniri vel cogitari poitest: quanto magis angelica creatura, quae omnia caetera quae Deus condidit naturae dignitate praceediit?" (Ilbid. XI. 15, PL 41, 331).

14 "Quamvis eit aquas, quod perversissimae atque impiae vanitatis est, negent quidam factas a Deo, quoniam nusiquam scriptum est, Dixit Deus, Fiant aquae. Quod possunt simili vanitate etiam de terra dicere; nusquam enim legitur, Dixit Deus, Fiat terra. Sed, inquiunt, scriptum est, In principio fecit Deus caelum et terram. Illic erigo et aqua initielligenda esit: Uno enim nomine utrumque comprehensum est. Nam ipsius est mare, sicuit in Psalmo legitur, et ipse fecit illud, et aridam terram manus eius finxerunt" (Ps. 94, 5)" (Ibid. XI, 34, PL 41, 348).

15 "Merito igitur vera religio, quae mundi univexsi eum, animalium quoque universorum, hoc est et animarum et corporum, conditorem agnoscit et praedicat" (Ibid. XII, 27, 1, PL 41, 376). 
Que Dios ha creado todas las cosas significa a su vez que ningún ser creado puede ser creador de otra cosa inferior. Platón decía que los animales y los cuerpos mortales han sido creados por los dioses inferiores o demiurgos, a su vez creados por el Dios supremo. Contra esto Agustín declara explícitamente:

«Neque enim fas est ullius naturae quamlibet minimae mortalisque crea* torem nisi Deum credere ac dicere, et antequam possit intelligi» ${ }^{16}$.

Hay que distinguir entre la creación, obra exclusiva de Dios, y la fabricación, simple cambio de forma en el ser ya existente, gracias a la manipulación del artista o del artesano ${ }^{17}$.

PROCESO DE LA CREACIÓN.

Tenemos por lo tanto que la creación es obra exclusiva de Dios. Pero ¿cómo realizó Dios esta obra? En otros lugares de sus escritos San Agustín expone ampliamente su pensamiento sobre esta cuestión. La creación es simultánea y virtual, es decir, todo fue creado al mismo tiempo, pero no en la forma actual, sino en una especie de gérmenes o razones seminales, que desarrollándose darían lugar a la infinita variedad de creaturas ${ }^{18}$. En el proceso de aparición de las

16 Ibid. XII, 24, PL 41, 373-374.

17 "Cum enim alia sit species' quae adhibetur extrinsecus cuicumque materiae corporali, sicut operantur homines figulli et fabri atque id genus opifices, qui etiam pingunt et effingunt formas similes corporibus animalium; alia vero quae intrinsecus' efficientes causas habet de secreito et occulto naturae viventis atque intelligentis arbitrio, quae non solum naturales corporum species, verum etiam ipsas animantium animas, dum non fit, facit; supradicta illa species artificibus quibusque tribuatur; haec autem altera nonnisi uni antifici creatori et conditori Deo, qui mundum ipsum et, angelos sine ullo munido et sine ullis angelis fecit... cuius occulta poitentia cuncta penetrans incontaminabili praesentia facit esse quidquid: aliquo modo est, in quanitumcumque est; quia nisi faciente illo, non tale vel tale esset, sed prorsus esse non potest" (Ibid. XII, 25, PL 41, 374375). Cf. también el capítulo 26, en el cuall San Agustín rechaza la opinión de los pilatónicos con un argumento "ad hominem" incontrovertible: Si ilos cuerpos de los hombres son las cárceles del alma, ¿cómo es posible renidir culto, como vosoitros proclamáis, a los dioses inferiores, creadores de estas cárceles inmundas?

18 "Haec autem propter senarii numeri perfectionem, eodem die sexies repetito, sex diebus perfecta narrantur: non quia Deo necessaria fuerit mora temporum, quasi non potuerit creare omnia simul, quae deinceps congruis motibus peragerent tempora; sed quia per senarium numerum est operum significata perfectio" (Ibid. XI, 30, PL 41,343). "Nimirum ergo si ad istorum dierum opera Dei pertinenth Angeli, ipsi sunt lux illa quae diei nomen accepit, cuius unitas ut commendaretur, non est dictus dies primus, sed dies unus. Nec alius est dies secundus aut tertius, aut caeteri, sed idem ipse unus ad implendum senarium vel septenarium numerum repetitus esit" (Ibid. XI, 9, PL 41, 324). Cf. De 
cosas San Agustín distingue dos momentos principales, creación de una materia informe, y formación de las cosas a partir de esta materia ${ }^{19}$. Pero en estos libros de La Ciudad de Dios el Santo apenas hace alusión a esta temática que, por otra parte, queda completamente al margen de la estructura de la obra ${ }^{20}$.

\section{EL VERBo y LA CREACIÓN.}

En la creación del universo Dios no obra sin saber lo que va a salir de sus manos, sino que sigue un plan bien preciso y determinado. Dios conoce previamente todas y cada una de las cosas que va a crear, y porque las conoce puede crearlas:

«Caeterum dictus est in Scripturis sanctis Spiritus sapientiae multiplex (Sap. 7, 22), eo quod multa in se habeat; sed quae habet, haec et est, et ea omnia unus est. Neque enim multae, sed una sapientia est, in qua sunt immensi quidam atque infiniti thesauri rerum intelligibilium, in quibus sunt omnes invisibiles atque incommutabiles rationes rerum, etiam visibilium et mutabilium, quae per ipsam factae sunt. Quoniam Deus non aliquid nesciens fecit, quod nec de quolibet homine artifice recte dici potest: porro, si sciens fecit omnia, ea utique fecit quae noverat. Ex quo occurrit animo quiddam mirum, sed tamen verum, quod iste mundus nobis notus esse non posset, nisi esset; Deo autem nisi notus esset, esse non posset» ${ }^{21}$.

Gen. ad lit. imp. lib. 11, 35, PL 34, 234; De Trin. III, 8, 13, PL 42, 875; De Gen. ad lit. II, 11, 24, PL 34, 272.

19 Cf. De Gen. contra Manich. I, 3, 5; 5, 9; 6, 10; 7, 11-12; 12, 18; II, 3, 4, PL 34, 176-181 y 198; De Gen. ad lit. imp. lib. 3. 10; 4, 11; 4, 13-15; PL 34, 223-226; De Gen. ad lit. V, 5, 16, PL 34, 326; Confes. XII, 3, 3; 4, 4; 7, 7; 8,$8 ; 12,15 ; 15,22 ; 17,25-26 ; 21,30$, PL 32,827 ss. Cuando se trata de los seres racionales se añade un tencer momento, la iluminación, como veremos al hablar de la creación de los ángeles y deil hombre.

20 "Cum ergo a caelo et terra coєperit, atque ipsa terra quam primitus fecit, sicut Scriptura consequenter eloquitur, invisibilis at incomposita, nondumque luce facta, utique tenebrae fuerint super abyssum, id est quamdam terrae et aquae indistinctam confusionem (ubi enim lux non est, tenebrae sint necesse est): deinde omnia creando disposita sint quae per sex dies consummata narrantur" (De Civ. Dei XI, 9, PL 41, 324). "In principio fecit Deus reaelum et terram: quibus nominibus universalis est significata creatura, vel spiritualis et corporalis, quod est credibilius; vel magnae duae mundi partes, quibus omnia quae creata sunt continentur, ut primitus eam totam proponeret, ac deinde partes eius secundum mysticum dierum numerum exsequeretur" (Ibid. XI, 33, PL 41, 347). Sobre este punto y sobre los demás problemas de la creación en San Agustín, cf. J. DE BuIC, Le processus de creátion d'après Saint Augustin, en "Mélanges F. Cavallera", Tolosa 1948, p. 179 ss.; J. O'TooLe, The Philosophy of creation in the writings of St. Augustine, Washington 1944; E. PoRTaliÉ, Saint Augustin, en "Dict. de Théol. Cath.", vol. I, 2.349-2.361.

21 De Civ. Dei XI, 10, 3, PL 41, 327. "Quid est enim aliud intelligendum in eo quod per omnia dicitur, Viditi Deus quia bonum est: nisi operis approbatio secundum artem facti, quae Sapientia Dei est? Deus autem usque adeo non cum 
Con estas palabras San Agustín expresa la teoría del ejemplarismo de las ideas ${ }^{22}$, teoría tomada de los platónicos y que él cristianiza identificando estas ideas ejemplares con la Sabiduría eterna de Dios, o sea el Verbo, por quien fueron hechas todas las cosas:

«Numquidnam ibi fuit iste propheta, quando fecit Deus caelum et terram? Non; sed ibi fuit Sapientia Dei, per quam facta sunt omnia» ${ }^{23}$.

El Verbo es el Mediador de la creación. En El radica la infinita Sabiduría divina, causa ejemplar de las creaturas y principio de todo ser:

«Atque illud quod dictum est, In principio, non ita dictum tanquam primum hoc factum sit, cum ante fecerit Angelos: sed quia omnia in sapientia fecit, quod est Verbum eius, et ipsum Scriptura nominavit; sicut ipse in Evangelio Judaeis quaerentibus quis esset, respondit se esse principium» 24.

\section{LA TRINIDAD EN LA CREACIÓN.}

En este tema de la creación por el Verbo se insinúa ya la doctrina de la creación como obra de las tres divinas Personas de la Trinidad, doctrina que San Agustín desarrolla brevemente al hablar de la bondad de Dios como causa única de la creación, en contra del dualismo maniqueo.

«Sed si nihil aliud est bonitas divina quam sanctittas, profecto et illa diligentia rationis est, non praesumptionis audacia, ut in operibus Dei secreto

factum est, tunc didicit bonum, ut nihil eorum fieret, si ei fuisset incognitum. Dum ergo videt quia bonum est, quod misi vidisset antequam fieret, non utique fiereit; docet bonum esse, non discit" (Ibid. XI, 21, PL 41, 333).

22 "Nos itaque ista quae fecisti videmus, quia sunt, tu autem quia vides ea sunt. Et nos foris videmus quia sunt, et intus quia bona sunt: tu autem ibi vidisti facta, ubi vidisti facienda" (Confes. XIII, 38,53, PL 32, 868).

${ }_{23}$ De Civ. Dei XI, 4, 1, PI 41, 319. “...participes lucis aeternae, quod est ipsa incommutabilis Sapientia Dei, per quam facita sunt omnia, quem dicimus Unigenitum Dei Filium" (Iibid. XI, 9, PL 41, 325). "Si autem non solum quis fecerit, verum etiam per quid fecerit; satis essett ita enuntiari: Et dixit Deus, Fiat lux, et facta est lux; ut non tantum Deum, sed etiam per Verloum lucem fecisse nossemus" (Ibid. XI, 21. PL 41, 334).

24 Ibid. XI, 32, PL 41, 345. "Sive in principio, quia primo fecit, sive quod convenientius intelligitur, In principio, quia in Verbo unigenito fecit, scriptum sit, In principio fecit Deus caelum et terram" (Ibid. XI, 33, PL 41, 347). San Agustín repite incesantemente a lo largo de toda su obra que el Verbo es la Sabiduría y el Poder del Padre, y que por El fueron hechas todas las cosas. Cf. por ejemplo: De Vera relig. 43, 81, PL 34, 159; De Gen. contra Manich. I, 2, 3, PL 34, 174; Confes. XI, 9, 11, PL 32, 813; De Trin. IV, 1, 3, PL 42, 888; In Joh. Evang. 1, 5; 1, 9; 18, 6; 18, 9;21, 4; 39, 1, PL 35, 1381, 1539, 1566. 
quodam loquendi modo, quo nostra exerceatur intentio, eadem nobis insinuata intelligatur Trinitas, unamquamque creaturam quis fecerit, per quid fecerit, propter quid fecerit. Pater quippe intelligitur Verbi, qui dixit, Fiat. Quod autem illo dicente factum est, procul dubio per Verbum factum est. In eo vero quod dicitur, Vidit Deus quia bonum est, satis significatur Deum nulla necessitate, nulla suae cuiusquam utilitatis indigentia, sed sola bonitate fecisse quod factum est, id est quia bonum est: quod ideo, postquam factum est, dicitur, ut res quae facta est congruere bonitati propter quam facta est, indicetur. Quae bonitas si Spiritus sanctus recte intelligitur, universa nobis Trinitas in suis operibus intimatur» 25 .

Si la creación es obra de la Trinidad, este origen trinitario debe haber dejado sus huellas, sus vestigios, en las criaturas. Ya la división tripartita de la filosofía en natural, racional y moral, es un dato significativo, aun cuando los filósofos no hayan conocido la Trinidad ${ }^{26}$. Pero esta imagen trinitaria aparece principalmente en el hombre, la más perfecta de las criaturas, y por tanto la que más se parece a su divino modelo y creador:

«Et nos quidem in nobis, tametsi non aequalem, imo valde longeque distantem, neque coaeternam, et quo brevius totum dicitur, non eiusdem substantiae, cuius est Deus, tamen qua Deo nihil sit in rebus ab eo factis natura propinquius, imaginem Dei, hoc est summae illius Trinitatis, agnoscimus, adhuc reformatione perficiendam, ut sit etiam similitudine proxima. Nam et sumus, et nos esse novimus, et id esse ac nosse diligimus» 27 .

El ser, la ciencia y el amor son pues las tres categorías que reflejan en el hombre la Trinidad, el Padre Creador, el Verbo, Sabiduría de Dios, y el Espíritu Santo, amor substancial del Padre y del Hijo.

Pero la imagen trinitaria no se agota en la naturaleza humana.

25 De Civ. Dei XI. 24, PL 41, 338. "Non e contrario referam contentionem maxime quia hoc me delectat pilurimum, quod etiam in summo exordio sancti libri Geneseos Trinitas commendatur. Cum enim ita dicitur, In prinicipio fecit Deus caelum eit terram, ut Pater fecisse intelligatur in Filio, sicut attestatur Psalmus, ubi Iegitur, Quam magnificata sunt opera tua, Domine! ommia in sapientia fecisti (Ps. 103, 24): convenientissime paulo post commemoratur etiam Spiritus sanctus. Cum enim dictum esset, qualem terram Deus primitus fecerit, vel qualem molem materiamve futurae constructionis mundi caeli et terrae nomine nuncupaverit, subiiciendo et addendo, Terra autem erat invisibilis et incomposita, et tenebrae erant super abysum: mox ut Trinitatis commemoratio compleretur, Et Spiritus, inquit, Dei superferebatur super aquam" (Ibid. XI, 32, PL 41. 345). Cf. thambién De vera relig. 7, 13, PL 34, 128; Enchir. 9, 3, PL 40, 235; Confes. XIII, 5, 6, PL 32, 847.

26 De Civ. Dei XI, 25, PL 41, 338.

27 Ibid. XI, 26, PL 41, 339. 
Los mismos animales y cosas inanimadas reflejan en cierto modo y conservan algunos vestigios de su origen trinitario. Todas las cosas son, tienden a la conservación de ese ser y, en cierto sentido, conocen, aunque no a la manera humana, lo que es necesario para su conservación ${ }^{28}$. He aquí la huella de la Trinidad en todo lo creado, que San Agustín nos descubre con su mirada penetrante, ansiosa de encontrar los reclamos que Dios ha dejado en su obra ${ }^{29}$.

\section{La bONDAD DE Dios, CAUSA DE LA CREACión.}

El único motivo de la creación es la bondad divina, su deseo de comunicar a otros seres las riquezas de su vida intratrinitaria. Ninguna necesidad tenía de crear el universo, El, que es completamente autosuficiente «cui nihil ex eius operibus adderetur» ${ }^{30}$.

«Si ergo quaerimus quis fecerit, Deus est. Si per quid fecerit, dixit, Fiat, et facta est. Si quare fecerit, Quia bona est. Nec auctor est excellentior Deo, nec ars efficacior Verbo, nec causa melior quam ut bonum crearetur a Deo bono. Hanc etiam Plato causam condendi mundi iustissimam dicit, ut a bono Deo bona opeta fierent» 31 .

San Agustín defiende la bondad de Dios como causa única de la creación en contra de los maniqueos, según los cuales Dios se vio obligado a crear los seres mundanos para defenderse de los ataques

28 Ibid. XI, 27-28, PL, 41, 340-342. La imagen de la Trinidad no es algo estático, sino algo que debemos perfeccionar hasta llegar a la máxima semejanza posible con Dios: "Quoniam igitur homines sumus, ad nostri Creatoris imaginem creati, cuius est vera aeternitas, aeterna veritas, aeterna et vera charitas, estrque ipsa aeterna et vera et chara Trinitas, neque confusa, neque separaita; in iis quidem rebus quae infra nos sunt, quoniam et ipsa nec aliquo modo essent, nec aliqua specie continerentur, nec aliquem ordinem vel appeterent vel tienerent, nisi ab illo facta essent qui summe est, qui summe sapiens est, qui summe bonus est: tanquam per omnia quae fecit mirabili stabilitate currentes, quasi quaedam eius alibi magis, alibi minus impressa vestigia colligamus; in nobis autem ipsis eius imaginem contuentes, tanquam minor ille evangelicus filius ad nosmettipsos reversi surgamus (Lc. 15, 18), ut ad illum redeamus a quo peccando recesseramus. Ibi esse nostrum non habebit mortem, ibi nosse nostrum non habebit errorem, ibi amare nostrum non habebit offensionem" (Ibid. XI, 28, PL 41, 324).

29 Los textos sobre los vestigios de la Trinidad en las criaturas son innumerables. Es una cuestión de la que San Agustín siempre se ha preocupado y que ha estudiado ampliamente. A modo de ejemplo podemos citar los siguienties pasajes: De vera relig. 7, 13, PL 34, 128; De Trin. VI, 10, 11; VII, 6, 12; $\mathrm{IX}, 2,2$; X, 11, 17; XI, 1, 1; XI, 2, 2; XI, 3, 6; XI, 7, 11; XII, 4, 4; XIII; 20, 26; XIV, 2, 4; XIV, 12, 15; XV, 22, 24, PL 42, 931 ss.; De Gen. ad lit. imp. lib. 1, 2, PL 34, 221.

30 De Civ. Dei XI, 21, PL 41, 334.

31 Ibi.d. XI, 21, PL 41, 334. 
del principio malo, que se rebelaba contra $\mathrm{El}^{32}$, y también en contra de Orígenes: éste defiende que las almas fueron creadas antes del mundo, y que habiendo pecado, fueron condenadas a vivir dentro de los cuerpos. Según esto la causa de la creación del mundo no fue la bondad divina, sino la necesidad de cohibir el pecado de las almas y el deseo de castigarlas. Orígenes, dice San Agustín, no comprende que todas las cosas fueron creadas buenas y perfectas y que, si existen males en el mundo, esto se debe al pecado, causa del mal en el mundo, pero no causa del mundo como un mal. Además, si es verdad lo que dice Orígenes, el volumen y la pesadez del cuerpo deberían estar en proporción a la gravedad y cantidad de los pecados de las almas, lo cual no es cierto, pues vemos que los demonios, máximos pecadores, no han sido castigados a vivir en un cuerpo terrestre $^{33}$.

El Dios eterno no tiene, por tanto, ninguna necesidad del mundo, como lo prueba su eternidad feliz: sólo su infinita bondad le impulsó a realizar tal obra:

«Hinc eis qui talia videre possunt mirabiliter fortassis ostendens, quam non eis indiguerit, sed eas gratuita bonitate condiderit, oum sine illis ex aeternitate initio carente in non minore beatitate permansit» 34 .

Con el tema de la bondad de Dios como causa de la creación está relacionado el tema del dualismo y de la eternidad del mundo o de la materia.

La eternidad de la materia y del mundo es un lugar común en toda la filosofía griega y en el pensamiento antiguo. San Agustín rechaza categóricamente esta opinión, como contraria a la verdad:

«Sed quid placuit Deo aeterno tunc facere caelum et terram, quae antea non fecisset? Qui hoc dicunt, si mundum aeternum, sine ullo initio, et ideo nec a Deo factum videri volunt, nimis aversi sunt a veritate, et letali morbo impietatis insaniunt» 35 .

Ya vimos que la creación del mundo es una verdad indiscutible que nos es conocida por las Sagradas Escrituras y, por la misma

32 Ibid. XI, 22, PL 41, 335.

33 Ibid. XI, 23, 1-2, PL 41, 336-337.

34 Ibid. XII, 17, 2, PL 41, 367.

35 Ibid. XI, 4, 2, PL 41, 319. 
razón, que descubre en las cosas la marca de su creaturalidad y las huellas de su Creador.

San Agustín ha luchado continuamente, desde su conversión, contra los maniqueos, que admitían la existencia de un principio malo, eterno, en continua batalla contra el principio bueno o Dios ${ }^{36}$. Los ecos de esta polémica se dejan sentir todavía en estos libros de La Ciudad de Dios. San Agustín refuta sin piedad toda clase de dualismo, funesto error contrario a la verdad más profunda y fundamental: la existencia de un solo Dios bueno.

Si se pregunta, ¿quién es, pues, el creador del mal, dado que Dios es bueno?, San Agustín responde con su famosa teoría del mal como privación de bien, repetida hasta la saciedad en todas sus obras antimaniqueas. El mal no es algo positivo, como las otras cosas, sino la negación de algo, la privación de un bien, la nada:

«Cum omnino natura nulla sit malum, nomenque hoc non sit nisi privationis boni» 37 .

Toda naturaleza en sí es buena, y el mismo mal o vicio da pruebas de la bondad de la naturaleza a la que daña:

«Omne autem vitium naturae nocet, ac per hoc contra naturam est. Ab illa igitur quae adhaeret Deo, non natura differt ista, sed vitio: quo tamen etiam vitio valde multumque laudabilis ostenditur ipsa natura. Cuius enim recte vituperatur vitium, procul dubio natura laudatur. Nam recta vitii vituperatio est, quod illo dehonestatur natura laudabilis» 38 .

Por lo tanto el mal no puede ser objeto final ni resultado de la acción creadora de Dios, ni de ningún principio malo, coeterno y contrario al Dios bueno, simplemente porque el mal no es ser, sino carencia de ser, pero carencia de ser debido y necesario, y en

36 Cf. Confes. IV, 15, 24, PL 32, 703; De vera relig. 9, 16, PL 34, 129; Confes. V, 10, 20, PL 32, 715; en general en todas' las obras de la controversia maniquea, como el De natura boni contra Manichaeos, De Genesi contra Manichaeos, etc.

37 De Civ. Dei XI, 22, PL 41, 335. "Mali enim nulla natura est; sed amissio boni, mali nomen accepit" (Ibid. XI, 9, PL 41, 325). San Agustín repite constantemente esta idea en su polémica con los maniqueos; cf. por ejemplo: De vera relig. 13, 26; 23, 44, PL 34, 133 y 141; De nat. boni 4, PL 42, 553; De mor. Manich. II, 2, 2; 3, 5; 4, 6, PL 32, 1.345 ss.; De Gen. ad lit. VIII, 14, 31, PL 34, 384.

38 De Civ. Dei XII, 1, 3, PL 41, 350. 
esto radica su maldad ${ }^{39}$. Además es imposible que exista otro principio eterno y contrario a Dios, porque Dios es el sumo ser, y al ser sólo se opone el no ser:

«Haec dicta sint, ne quisquam, cum de angelis apostaticis loquimur, existimet eos aliam velut ex alio principio habere potuisse naturam, nec eorum naturae auctorem Deum. Cuius erroris impietate tanto quisque carebit expeditius et facilius, quanto perspicacius intelligere potuerit, quod per angelum dixit Deus, quando Moysem mittebat ad filios Israel: Ego sum, qui sum (Ex. 3, 14). Cum enim Deus summa essentia sit, hoc est summe sit, et ideo immutabilis sit; rebus quas ex nihilo creavit, esse dedit, sed non summe esse, sicut est; et aliis dedit esse amplius, aliis minus; atque ita naturas essentiarum gradibus ordinavit... Ac per hoc ei naturae, quae summe est, qua faciente sunt quaecumque sunt, contraria natura non est, nisi quae non est. Ei quippe quod est, non esse contrarium est. Et propterea Deo, id est summae essentiae, et auctori omnium qualiumcumque essentiarum, essentia nulla contraria est» 40 .

No existe pues ningún principio eterno fuera de Dios. El dualismo maniqueo es una aberración nacida de mentes sin piedad y sin conocimiento. ¿De dónde procede, entonces, el mal, dado que no puede venir de Dios ni de ningún principio malo? El mal procede de la voluntad que se rebela contra Dios, dice San Agustín tratando del pecado de los ángeles y de los primeros hombres. El mal consiste en la defección de Dios, sumo bien, por la elección de un bien menor de manera desordenada ${ }^{41}$. Y la voluntad puede apartarse de Dios porque ha sido creada de la nada y por lo tanto lleva en su seno la contingencia y la mutabilidad, por oposición al Verbo divino, que ha sido engendrado desde toda la eternidad:

«Hoc scio, naturam Dei nunquam, nusquam, nulla ex parte posse deficere; et ea posse deficere, quae ex nihilo facta sunt. Quae tamen quanto magis sunt, et bona faciunt (tunc enim aliquid faciunt), causas habent efficientes; in quantum autem deficiunt, et ex hoc mala faciunt (quid enim tunc faciunt nisi vana) causas habent deficientes. Itemque scio in quo fit mala

39 "De inimicis Dei, non per naturam sed per contrariam voluntatem, quae cum ipsis nocet bonae utique naturae nocet; quia vitium si non nocet non est" (Ibid. XII, 3, PL 41, 350).

40 Ibid. XII, 2, PL 41, 350.

41 Cf. De Civ. Dei XII, 1, 3, PL 41, 349, donde San Agustín demuestra que el adherirse a Dios es el sumo bien de la naturaleza creada, y que por lo tanto el apartarse de El constituye un pecado que vicia la naturaleza. "Non itaque esset vitium recedere a Deo, nisi naturae, cuius id vitium est, potius competeret esse cum Deo" (De Civ. Dei XI, 17, PL 41, 331). 
voluntas, id in eo fieri, quod si nollet, non fieret: et ideo non necessarios sed voluntarios defectus iusta poena consequitur. Deficitur enim non ad mala, sed male; id est, non ad malas naturas, sed ideo male quia contra ordinem naturarum ab eo quod summe est ad id quod minus est (...) Ac per hoc qui perverse amat cuiuslibet naturae bonum, etiamsi adipiscatur, ipse fit in bono malus, et miser meliore privatus» ${ }^{42}$.

El mal procede de la mala voluntad, pero ¿de dónde viene al hombre y al ángel esta mala voluntad? ¿Cuál es la causa de la mala voluntad? Ninguna, dice San Agustín:

«Huius porro malae voluntatis causa efficiens si quaeratur, nihil invenitur. Quid est enim quod facit voluntatem malam, cum ipsa faciat opus malum? Ac per hoc mala voluntas efficiens est operis mali, malae autem voluntatis efficiens est nihil» ${ }^{43}$.

A continuación de estas palabras San Agustín desarrolla un profundo argumento para probar que no puede existir una causa eficiente de la mala voluntad. En definitiva, viene a decir, si existe una causa eficiente de la mala voluntad, esta causa debe ser algo, tener un cierto ser, una cierta naturaleza, y como tal es algo bueno; pero entonces, ¿cómo podemos decir que el mal proviene del bien?:

«...et inveniet voluntatem malam non ex eo esse incipere quod natura est, sed ex eo quod de nihilo natura facta est. Nam si natura causa est voluntatis malae, quid aliud cogimur dicere, nisi a bono fieri malum, et bonum

42 Ibid. XII, 8, PL 41, 355. "Mala vero voluntas prima, quoniam omnia mala opera praecessit in homine, defectus potius fuit quidam ab opere Dei ad sua opera, quam opus ullum. Et ideo mala opera, quia secundum se, non secundum Deum: ut eorum operum tanquam fructim malorum voluntas ipsa esset velut arbor mala, aut ipse homo in quantum malae voluntatis. Porro mala voluntas, quamvis! non sit secundum naturam, sed contra naturam, quia vitium est'; tamen eius naturae est, cuius vitium est, quod nisi in natura non potest esse: sed in ea quam creavit ex nihilo, non quam genuit Creator de semetipso, sicut genuit Verbum, per quol facta sunt omnia. Quia etsi de terrae pulvere Deus finxit hominem; eadem terra omnisque terrena materies omnino de nihilo est, animamque de nihilo factam dedit compori, cum factus est homo... Usque adeo autem mala vincuntur a bonis, ut quamivis sinantur esse ad demonstrandum quam possit et ipsis bene uti iustitia providentissima Creatoris; bona tamen sine malis esise posisinit, sicut Deus ipse verus et summus, sicut omnis super istum caliginosum aerem caelestis invisibilis visibilisque creatura; mala vero sine bonis esse non possint, quoniam naturae in quibus sunt, in quantum naturae sunt, utique bonae sunt. Detrahitur porro malum, non alliqua natura quae accesserat vel ulla eius parte sublata, sed ea quae vitiata ac depravata fuerat, sanata aitque correcta. Arbitrium igitur voluntatis tunc est vere liberum, cum vitiis peccatisque non servit. Tale datum est a Deo: quod amissum proprio vitio, nisi a quo dari potuit, reddi non poset" (Ibid. XIV, 11, 1, PL 41, 418).

43 Ibid. XII, 6, PL 41,353 . 
esse causam mali? siquidem a natura bona fit voluntas mala. Quod unde fieri potest, ut natura bona, quamvis mutabilis, antequam habeat voluntatem malam, faciat aliquid mali, hoc est, ipsam voluntatem malam?» ${ }^{44}$.

La conclusión es entonces clara: No existe una causa eficiente de la mala voluntad, sino deficiente:

«Nemo igitur quaerat efficientem causam malae voluntatis: non enim est efficiens, sed deficiens; quia nec illa affectio est, sed defectio. Deficere namque $a b$ eo quod summe est, ad id quod minus est, hoc est incipere habere voluntatem malam. Causas porro defectionum istarum, cum efficientes non sint, ut dixi, sed deficientes, velle invenire, tale est ac si quisquam velit videre tenebras, vel audire silentium: quod tamen utrumque nobis notum est; neque illud nisi per oculos, neque hoc nisi per aures; non sane in specie, sed in speciei privatione» ${ }^{45}$.

La misma defección de Dios es pues al mismo tiempo mala voluntad y la causa de esa mala voluntad, causa no eficiente, sino deficiente, en cuanto que ese apartarse de Dios no es algo positivo que pueda dar origen a otra cosa, sino algo negativo, la negación y la repulsa de la creatura a seguir adherida al Sumo Bien ${ }^{46}$.

Por consiguiente, el mal no procede de Dios, sino de la mala voluntad de la creatura racional. Pero esto no quiere decir que el mal esté completamente fuera del control de Dios. Al contrario, Dios omnipotente, aun no queriendo el mal, sabe someterlo bajo su dominio y ordenarlo a la consecución de mayores bienes:

«Sed Deus, sicut naturarum bonarum optimus creator est, ita malarum voluntatum iustissimus ordinator; ut cum male illae utuntur naturis bonis, ipse bene utatur etiam voluntatibus malis» ${ }^{47}$.

Dios preveía que sus creaturas obrarían el mal; si a pesar de todo Dios realiza la obra de la creación es porque sabe cómo utilizar ese mal para un bien mayor:

\footnotetext{
44 Ibid. XII, 6, PL 41, 355.

Ibid. XII, 7, PIL 41, 355.

"Cum ergo malae voluntatis efficiens naturalis, vel, si dici potest essentialis nulla sit causa; ab ipsa quippe incipit spirituum mutabilium malum, quo minuitur atque depravatur naturae bonum, nec talem voluntatem facit nisi defectio, qua deseritur Deus, cuius defectionis etiam causa utique deficit" (Ibid. XII, 9, 1, PL 41, 356).

47 Ibid. XI, 17, PL 41, 332.
} 
«Neque enim Deus ullum, non dico Angelorum, sed vel hominum crearet, quem malum futurum se esse praescisset, nisi pariter nosset quibus eos bonorum usibus commodaret, atque ita ordinem saeculorum tanquam pulcherimum carmen ex quibusdam quasi antithesis honestaret (...). Sicut ergo ista contraria contrariis opposita sermonis pulchritudinem reddunt, ita quadam, non verborum, sed rerum eloquentia contrariorum oppositione saeculi pulchritudo componitur. Apertissime hoc positum est in libro Ecclesiastico, hoc modo: Contra malum bonum est, et contra mortem vita: sic contra pium peccator. Et sic intuere in omnia opera altissimi bina et bina, unum contra unum (Eccl. 33, $15) \gg 48$.

La creación es, pues, como un poema grandioso, embellecido con la antítesis armónica del bien y el mal. Dios no quiso el mal, pero una vez introducido en el mundo lo acepta como un hecho, lo domina y lo usa en la composición de este gran poema. La misma idea repite San Agustín un poco más adelante, usando en este caso la metáfora de la pintura:

«Ubi si nemo peccasset, tantummodo naturis bonis esset mundus ornatus et plenus: et quia peccatum est, non ideo cuncta sunt impleta peccatis, cum bonorum longe maior numerus in caelestibus suae naturae ordinem servet. Nec mala voluntas, quia naturae ordinem servare noluit, ideo iusti Dei leges omnia bene ordinantis effugit. Quoniam sicut pictura cum colore nigro, loco suo posita, ita universitas rerum, si quis possit intueri, etiam cum peccatoribus pulchra est quamvis per se ipsos consideratos sua deformitas turpet» ${ }^{49}$.

\section{LA CREACIÓN EN EL TIEMPO Y CON EL TIEMPO.}

Hablando de la bondad divina como causa única de la creación hemos ido desarrollando los problemas que se plantean con respecto a este tema, es decir, en una palabra, la causa y la explicación del mal. Ahora debemos retroceder un poco, en un sentido lógico, y explicar el problema, planteado y resuelto por San Agustín, de la compaginación de la eterna inmutabilidad divina con la creación en el tiempo.

El problema es planteado por la doctrina maniquea, que se

48 Ibid. XI, 18, PL $41,332$.

49 Ibid. XI, 23, 1, PL 41, 336. En la oración introductoria de los Soliloquios San Agustín se dirige así a Dios: "Deus, per quem universitas, etiam cum sinistra parte, perfecta est" (Sol. I, 1, 2, PL 32, 869). Sobre la cuestión del mal en San Agustín puede consultarse: Régis Jolivet, Le problème du mal d'après Saint Augustin, Paris 1936, 168 pgs. 
interrogaba por qué Dios creó el mundo en un determinado tiempo y no antes, ya que podía haberlo hecho desde la eternidad. Además, ¿no supone la creación un cambio en la ciencia y en la voluntad divinas? ${ }^{50}$.

La cuestión de la vida y actividad divinas antes de la creación del mundo es una cuestión sin sentido, dice San Agustín. Pues antes de la creación del mundo no existía el tiempo, creado con él, y por lo tanto es absurdo hablar de antes y después en la inmutable eternidad de Dios ${ }^{51}$. La cuestión es propia de mentes insensatas y soberbias, que pretenden escudriñar lo impenetrable ${ }^{52}$. A pesar de lo cual San Agustín trata de hacer algunas especulaciones para responder a la dificultad, pero en definitiva termina por decir que ignora qué es lo que hacía Dios ${ }^{53}$.

Lo que sí es cierto es que la creación no supone un cambio en la ciencia ni en la voluntad divinas:

«Non quod ullo modo Dei scientia varietur, ut aliud in ea faciant quae nondum sunt, aliud quae iam sunt, aliud quae fuerunt. Non enim more nostro ille vel quod futurum est prospicit, vel quod praesens est aspicit, vel quod praeteritum est respicit; sed alio modo quodam a nostrarum cogitationum consuetudine longe alteque diverso. Ille quippe non ex hoc in illud cogitatione mutata, sed omnino incommutabiliter videt; ita ut illa quidem quae temporaliter fiunt, et futura nondum sint, et praesentia iam sint, et praeterita iam non sint, ipse vero haec omnia stabili ac sempiterna praesentia comprehendat: nec aliter oculis, aliter mente; non enim ex animo constat et corpore: nec aliter nunc, aliter antea et aliter postea; quoniam non sicut nostra, ita eius

50 La cuestión es tratada por San Agustín en diversos lugares de sus obras; por ejemplo: De Gen. contra Manich. I, 2, 4, PL 34, 175; Confes. XI, 10,12 ; XIII, 2, 2, PL 32,814 y 845 .

51 ¿Qué más da, dice San Agustín hablando de la creación del hombre, que lo haya creado anites o después, si la mayor cantidad de siglos imaginable, comparada con la eternidad divina, es menos que una gota de agua comparada con la inmensidad de los océanos? Cf. De Civ. Dei XII, 12, PL 41, 359.

52 "Nonne ecce pleni sunt vetustatis suae qui nobis dicunt: quid faciebat Deus antequam faceret caelum et terram" (Confes. XI, 10, 12, PL 32, 814). "Qui autem dicit, quare voluit facere caelum et terram? maius aliquit quaerit quam est voluntas Dei: nihil autem maius inveniri potesit. Compescat erga se humana temeritas, et id quod non est non quaerat, ne id quod est non inveniat" (De Gen. contra Manich. I, 2, 4, PL 34, 175).

53 "Libentius enim responderim: Nescio, quod nescio, quam illud, unde irridetur qui alta initerrogavit et laudatur qui falsa respondit. Sed dico te, Deus noster, omnis creaturae creatorem; et si caeli et terrae nomine omnis creatura intelligitur, audenter dico: antequam faceret Deus caelum et terram, non faciebat aliquid. Si enim faciebat, qui.d nisi creaturam faciebat? Et utinam sic sciam, quidquid utiliter scire cupio, quemadmodum scio, quod nulla fiebat creatura, antequam fieret ulla creatura" (Confes. XI, 12, 14, PL 32, 815). 
quoque scientia trium temporum, praesentis videlicet et praeteriti vel futuri, varietate mutatur: apud quem non est immutatio, nec momenti obumbratio (Iac. 1, 17). Neque enim eius intentio de cogitatione in cogitationem transit, in cuius incorporeo contuitu simul adsunt cuncta quae novit: quoniam tempora ita novit nullis suis temporalibus notionibus, quemadmodum temporalia movet nullis suis temporalibus motibus» 54 .

En su eternidad todo está presente a Dios. La creación no aumenta su conocimiento de otros contenidos cognoscitivos, sino que, por el contrario, la creación es efecto de su conocimiento eterno y ejemplar: «Dum ergo videt quia bonum est, quod nisi vidisset antequam fieret, non utique fieret... ${ }^{55}$.

Del mismo modo la voluntad no cambia en Dios al crear el universo, porque es un decreto eterno, por encima del tiempo, el que ha dado origen a las cosas en un determinado tiempo:

«Si ergo credant et mundum ex tempore fieri potuisse, nec tamen ideo Deum in eo faciendo aeternum consilium voluntatemque mutasse» 56 .

La dificultad es que la mente humana está condicionada hasta lo más íntimo de sí misma por la temporalidad, y no es capaz de concebir una inmutabilidad sin tiempo, como la de Dios, en quien no existe pasado, presente y futuro, sino sólo la simplicidad soberana de un eterno presente sin principio ni fin, sin pasado ni futuro ${ }^{57}$.

La misma cuestión se le presenta al Santo cuando habla de la creación del hombre, y de nuevo responde con el mismo argumento:

«Quia cum ipse sit aeternus et sine initio, ab aliquo tamen initio exorsus est tempora, et hominem quem nunquam ante fecerat, fecit in tempore, non tamen novo et repentino, sed immutabili aeternoque consilio. Quis hanc valeat altitudinem investigabilem vestigare, et inscrutabilem perscrutari, secundum quam Deus hominem temporalem, ante quem nemo unquam hominum fuit, non mutabili voluntate in tempore condidit, et genus humanum ex uno multiplicavit? (...). Valde quippe altum est, et semper Deum fuisse, et hominem quem nunquam fecerat, ex aliquo tempore primum facere voluisse, nec consilium voluntatemque mutasse» 58 .

54 De Civ. Dei XI, 21, PL 41, 334.

55 Ibid. XI, $21, \mathrm{PL} 41,334$.

56 Ibid. XI, 4, 2, PL 41, 320 .

57 "Quis tenebit cor hominis, ut stet et videat, quomodo stans dictet futura et praeterita tempora nec futura nec praeterita aeiternitas?" Confes. XI, 11, 13, PI 32, 814).

58 De Civ, Dei XII, 14, PL 41, 362, 
Contra la objeción de los que afirman que todas las cosas se repiten, que han existido siempre y existirán de nuevo infinitas veces, pues la bondad de Dios no puede estar ociosa, sin hacer nada ${ }^{59}$, San Agustín defiende una vez más la inmutabilidad divina. No podemos medir la voluntad divina con el metro de nuestra voluntad mudable, incapaz de hacer una cosa nueva sin ningún cambio ${ }^{60}$. Dios, sin embargo, puede realizar una nueva obra sin cambiar de idea, con el eterno decreto de hacerla. El paso de la noexistencia a la existencia es un paso que se refiere sólo a las cosas, no a Dios, cuya voluntad permanece siempre la misma antes de la creación que después ${ }^{61}$.

En relación con este problema se halla el de la creación desde la eternidad. ¿Pudo Dios haber creado el mundo desde la eternidad? San Agustín no ve cómo esto pueda compaginarse con la temporalidad de las creaturas, si bien, en línea de principio, no repugnaría por parte de Dios, ya que $\mathrm{El}$ es eterno y omnipotente desde la eternidad:

59 "Bonitas autem eius nunquam vacua fuisse credenda est, ne sit temporalis eius operatio, cuius retro fuerit aeterna cessatio, quasi poenituerit eum prioris sine initio vacationis, ac propterea sit operis aggressus initium. Et ideo necesse est, inquiunt, eadem semper reipeti, eademque semper repetenda transcurrere..." (Ibid. XII, 17, 1, PL 41, 366).

60 "Has argumentationes quibus impii nostram simplicem pietatem, ut cum illis in circuitu ambulemus, de via recta conantur avertere, si ratio refutare non posset, fides irridere deberet. Huc accedit, quod in adiutorio Domini Dei nostri hos volubiles circulos, quos opinio confingit, ratio manifesta confringit. Hinc enim maxime isti errant, ut in circuitu falso ambulare, quam vero eit recto itinere malint, quod mentem divinam omnino immutabilem cuiuslibet infinitatis capacem, et innumera omnia sine cogitationis alteratione numerantem, de sua humana, mutabili, angustaque metiuntur. Et fit illis quod ait Apostolus: comparantes enim semetipsos sibimetipsis, non intelligunt. Nam quia illis quidquid novi faciendum venit in mentem novo consilio faciunt (mutabiles quippe mentes gerunt); profecto non Deum, quem cogitare non possunt, sed semetipsos pro illo cogitantes, non illum sed' se ipsos, nec illi, sed sibi comparant" (Ibid. XII, 17, 2, PL 41, 366).

61 "Nobis autem fas non est credere, aliter Deum affici cum vacat, aliter cum operatur: quia nec affici dicendus est, tanquam in eius natura fiat aliquid, quod non ante fuerit. Patitur quippe qui afficitur, et mutabile esit omne quod aliquid patitur. Non itaque in eius vacatione cogitetur ignavia, desidia, inertia; sicut nec' in eius opere labor', conatus, industria. Novit quiescens agere, et agens quiescere. Potest ad opus novum, non novum sed sempiternum adhibere consilium; nec poenitendo quia prius cessaverat, coepit facere quod non fecerat. Sed et si prius cessavit, et posterius operatus' est (quod nescio quemadmodum ab homine possit intelligi), hoc procul dubio quod' dicitur, prius et posterius in rebus prius non exsistentibus eit posterius exsistentibus fuit. In illo autem non alteram praecedenitem altera subsequens mutavit aut abstulit voluntatem, sed una eademque sempiterna et immutabili voluntate res quas condidit, et ut prius non essent egit, quamdiu non fuerunt, et ut posterius essent, quando esse coeperunt: hinc 
«Qui autem a Deo quidem factum fatentur, non tamen eum volunt temporis habere, sed suae creationis initium, ut modo quodam vix intelligibili semper sit factus, dicunt quidem aliquid, unde sibi Deum videntur velut a fortuita temeritate defendere, ne subito illi venisse credatur in mentem, quod nunquam ante venisset, facere mundum, et illi accidisse voluntatem novam, cum in ullo sit omnino mutabilis: sed non video quomodo eis possit in caeteris rebus ratio ista subsistere, maximeque in anima, quam si Deo coaeternam esse contenderint, unde illi acciderit nova miseria, quae nunquam antea per aeternum, nullo modo poterunt explicare» 62 .

San Agustín toma el ejemplo del alma, clara alusión a la doctrina platónica de la preexistencia de las almas, para refutar la creación $a b$ aeterno. ¿Cómo puede explicarse, se pregunta el Santo, la nueva miseria que sobreviene al alma, que ha sido creada desde la eternidad? Desarrollando el argumento, San Agustín llega a la conclusión de que no es necesario admitir la creación ab aeterno para defender la inmutabilidad divina ${ }^{63}$.

La dificultad se presenta de nuevo un poco más adelante, en un contexto distinto. Se trata de entender cómo Dios pueda ser siempre Señor sin tener creaturas sobre las cuales ejercer su Señorío ${ }^{64}$ :

«Ego quidem, sicut Dominum Deum aliquando dominum non fuisse dicere non audeo, ita hominem nunquam antea fuisse, et ex quodam tempore primum hominem oreatum esse dubitare non debeo» ${ }^{65}$.

eis qui talia videre possunt mirabiliter fortassis ostendens, quam non eis indiguerit, sed eas gratuita bonitate condiderit, cum sine illis ex aeternitate initio carente in non minore beatitate permansit" (Ibid. XII, 17, 2, PL 41, 367). Los htres capítulos siguientes: (XII, 18-20), en el fondo, no hacen más que continuar lesta prueba de la inmutabilidad divina, aduciendo diversos argumentos. La conclusión es la siguiente: "Quapropter quoniam circuitus illi iam explosi sunt, quibus ad easdem miserias necessario putabatur anima reditura; quid restat convenientius pietati, quam credere non esse impossibile Deo, et ea quae nunquam fecerit nova facere, et ineffabili praescientia voluntatem mutabilem non habere?" (Ibid. XII, 20, 4, PL 41, 371).

62 Ibid. XI, 4, 2, PL 41, 319.

63 Cf. De Civ. Dei XI, 4, 2, a continuación del texto citado anteriormente. Sobre la preexistencia de las almas, cf. De libero arbitrio III, 20, 57-58, PL 32, 1298; De Trin. XII, 15, 24, PL 42, 1011.

64. En el De Trinitate San Agustín afirma que Dios no ha sido Señor desde la eternidad, para no verse obligado a defender la eternidad de la creación: "Ecce Dominum esse non sempiternum habet, ne cogamur etiam sempiternam creaturam dicere, quia illa sempiterne non dominaretur, nisi etiam ista sempiterne famularetur. Sicut autem non potest esse servus qui non habet dominum, sic nec dominus qui non habet servum" (De Trin. V, 16, 17, PL 42, 922). Aquí San Agustín adimite el Señorío eterno de Dios, pero a la hora de explicar cómo pueda ser esto sin tener una creatura eterna a la que dominar, nos confesará su ignorancia.

65 De Civ. Dei XII, 15, 1, PL 41, 363. 
La fe nos obliga a admitir la creación temporal y la infinita perfección divina nos obliga a decir que Dios ha sido siempre Señor. Ahora bien, cómo estos dos factores se compaginen entre sí es una cuestión dificilísima, cuya solución, confiesa humildemente San Agustín, está por encima de sus fuerzas:

«Sed hoc si respondero eis qui requirunt quomodo semper creator, semper dominus fuit, si creatura serviens non semper fuit; aut quomodo creata est, et non potius creatori coaeterna est, si semper fuit: vereor ne facilius iudicer affirmare quod nescio, quam docere quod scio. Redeo igitur ad id quod Creator noster scire nos voluit: illa vero quae vel sapientioribus in hac vita scire permisit, vel omnino perfectis in alia vita scienda servavit, ultra vires meas esse confiteor. Sed ideo putavi sine affirmatione tractanda, ut qui haec legunt, videant a quibus quaestionum periculis debeant temperare, nec ad omnia se idoneos arbitrentur; potiusque intelligant quam sit Apostolo obtemperandum praecipienti salubriter ubi ait: Dico autem per gratiam quae data est mihi, omnibus qui sunt in vobis, non plus sapere quam oportet sapere; sed sapere ad temperantiam, sicut unicuique Deus partitus est mensuram fidei (Rom. 12, 3). Si enim pro viribus suis alatur infans, fiet ut crescendo plus capiat: si autem vires suae capacitatis excedat, deficiet antequam crescat» 66 .

San Agustín parte de los datos de fe y, basándose en ellos, busca la inteligencia de los mismos, la intelligentia fidei. Pero esta inteligencia tiene sus límites, y San Agustín no duda en reconocerlos, sin querer rebelarse contra ellos. No sabemos cómo Dios es Señor eternamente. Lo que es cierto y lo que se debe admitir a pesar de todo es que no ha existido ninguna creatura creada desde la eternidad:

«Quae saecula praeterierint antequam genus institueretur humanum, me fateor ignorare: non tamen dubito nihil omnino creaturae Creatori esse coaeternum» 67 .

Pues la creatura lleva en su esencia la marca de la temporalidad, y tan pronto como comenzase a existir comenzaría a existir también el tiempo:

66 Ibid. XII, 15, 3, PL 41, 365 .

67 Ibid. XII, 16, PL 41, 365. Cf. De Gen. contra Manich. I, 2, 4, PL 34, 175; De Gen. adi lit. imp. lib. 3, 8, PL 34, 223; Confes. XI, 30, 40; XII, 12, 15, PL 32,826 y $831 ;$ De Trin. V, 16, 17, PL 42, 922. 
«Si enim recte discernuntur aeternitas et tempus, quod tempus sine aliqua mobili mutabilitate non est, in aeternitate autem nulla mutatio est: quis non videat quod tempora non fuissent, nisi creatura fieret, quae aliquid aliqua motione mutaret; cuius motionis et mutationis cum aliud atque aliud, quae simul esse non possunt, cedit atque succedit, in brevioribus vel productioribus morarum intervallis tempus sequeretur? Cum igitur Deus, in cuius aeternitate nulla est omnino mutatio, creator sit temporum et ordinator, quomodo dicatur post temporum spatia mundum creasse, non video; nisi dicatur ante mundum iam aliquam fuisse creaturam, cuius motibus tempora currerent. Porro si Litterae sacrae maximeque veraces ita dicunt, in principio fecisse Deum caelum et terram (Gen. 1, 1), ut nihil antea fecisse intelligatur, quia hoc potius in principio fecisse diceretur, si quid fecisset ante caetera cuncta quae fecit; procul dubio non est mundus factus in tempore, sed cum tempore. Quod enim fit in tempore, et post aliquod fit, et ante aliquod tempus; post id quod praeteritum est, ante id quod futurum est: nullum autem posset esse praeteritum; quia nulla erat creatura, cuius mutabilibus motibus ageretur. Cum tempore autem factus est mundus, si in eius conditione factus est mutabilis motus» 68 .

El tiempo pues no existía antes de la creación, sino que fue creado junto con las creaturas, cuya mutabilidad constituye el fundamento del mismo. El tiempo es el paso de un estado a otro distinto, la medida del movimiento. Ahora bien, siendo Dios inmutable, no puede existir en El el tiempo, y por consiguiente no se puede hablar del tiempo antes de la creación del mundo ${ }^{69}$.

El análisis que San Agustín hace del tiempo es agudísimo, y nos recuerda las profundas reflexiones del libro XI de las Confesiones. Hablando de los ángeles, cuando afirma que han existido siempre, dice que esto no significa que sean eternos: han existido siempre, en el siempre de la temporalidad, no en el de la eternidad, porque siendo las primeras creaturas salidas de la mano de Dios,

68 De Civ. Dei XI, 6, PL 41, 321.

69 "Et sicut non est consequens ut fortuito potius quam ratione divina Deus, non alio, sed isto in quo est loco, mundum constituerit, cum pariter infinitis ubique patentibus nullo excellentiore merito posset hic eligi, quamvis eamdem divinam rationem, qua id factum est, nulla possit humana comprehendere: ita non est consequens ut Deo aliquid existimemus accidisse fortuitum, quod illo potius quam anteriore tempore condidit mundum, cum aequaliter anteriora tempora per infinitum retro spatium praeterissent. Quod si dicunt inanes esse hominum cogitationes quibus infinita imaginantur loca, cum locus nullus sit praeter mundum; respondetur eis, isto modo inaniter homines cogitare praeterita tempora vacationis Dei, cum nullum tempus sit ante mundum" (Iibid. XI, 5, PiL $41,321)$. "Sed ante, dico, aeternitate, non tempore. Quis enim alius creator est temporum, nisi qui fecit ea, quorum motibus currerent tempora?" (Ibid. XII, 25, PL 41, 375). 
son las que dieron origen al tiempo, por lo cual se puede decir que han existido siempre, pues han existido en todo tiempo:

«Sicut ergo dicimus creatum tempus, cum ideo semper fuisse dicatur, quia omni tempore tempus fuit: ita non est consequens, ut si semper fuerunt angeli, ideo non sint creati, ut propterea semper fuisse dicantur, quia omni tempore fuerunt; et propterea omni tempore fuerunt, quia nullo modo sine his ipsa tempora esse potuerunt. Ubi enim nulla creatura est, cuius mutabilibus motibus tempora peragantur, tempora omnino esse non possunt. Ac per hoc et si semper fuerunt, creati sunt; nec, si semper fuerunt, ideo Creatori coaeterni sunt. Ille enim semper fuit aeternitate immutabili: isti autem facti sunt; sed ideo semper fuisse dicuntur, quia omni tempore fuerunt, sine quibus tempora nullo modo esse potuerunt: tempus autem quoniam mutabilitate transcurrit, aeternitati immutabili non potest esse coaeternum» 70 .

Por consiguiente el tiempo ha sido creado en el mismo momento en que fue creada la primera creatura, ha comenzado a existir en el momento en que surgió la creatura mudable, cuya movilidad hace posible el paso del futuro al presente y del presente al pasado. Esta concepción del tiempo está en neto contraste con la concepción griega del eterno retorno. La concepción circular es inadmisible dentro de la doctrina cristiana de la creación y de la historia de la salvación. La concepción del eterno retorno, de la repetición infinita de todas las cosas, choca con la fe cristiana de la felicidad eterna de las almas. ¿Cómo puede afirmarse que un alma es feliz si ha de volver de nuevo al estado de la miseria pasada? Pues la felicidad perfecta lleva consigo la seguridad de que esa felicidad no tendrá fin, y el conocimiento de que esa seguridad no es engañosa ${ }^{71}$.

Del mismo modo, contra la concepción cíclica se levanta la cruz de Cristo, evento único e irrepetible que divide el tiempo en dos mitades, realizando su obra redentora de una vez para siempre:

«...absit, inquam, ut nos ita credamus. Semel enim Christus mortuus est pro peccatis nostris; resurgens autem a mortuis iam non moritur, et mors ei ultra non dominabitur (Rom. 6, 9): et nos post resurrectionem semper cum Domino erimus (I Thes. 4, 16), cui modo dicimus, quod sacer admonet

70 Ibid. XII, 15, 2, PL 41, 364. Todo este capítulo es un profundo análisis del tiempo.

71 Ibid. XII, 13, 1-2, PL 41, 360; XII, 20, 1-4, PL 41, 369. 
Psalmus, Tu Domine, servabis nos, et custodies nos a generatione hac in aeternum» 72 .

Nada más contrario a la fe cristiana que este desolante repetirse de las cosas, de los hombres, de las mismas situaciones; nada más contrario a la historia y a la misma concepción de la ciudad de Dios, que se va construyendo entre los límites de dos puntos terminales: la creación, como colocación de la primera piedra de esta ciudad, y el juicio escatológico, momento de la terminación y de la realización perfecta de la misma.

\section{LA CREACIÓN DE LOS ÁNGELES.}

Hemos estudiado hasta ahora las cuestiones generales sobre la creación, tal como aparecen en estos cuatro libros de $\mathrm{La}$ Ciudad de Dios. Ahora debemos comenzar a hablar de la creación de los ángeles y de los hombres y de su pecado, que da origen a la oposición entre las dos ciudades, la de Dios y la del mundo.

Empezamos con la creación de los ángeles, como hace el mismo

72 Ibid. XII, 13, 2, PL 41, 362. "Nunc enim contra opinionem disputamus, qua illi circuitus asserunitur, quibus semper eadem per intervalla temporum necesse esse repeti existimantur. Quaelibet autem illarum sententiarum de saeculis saeculorum vera sit, non eadem repetita, sed alterum ex alitero connexione ordinatissima procurrentia, liberatorum beatitudine sine ullo recursu miseriarum certissima permanente, sive saecula saeculorum aeterna sint temporalium tamquam dominantia subditorum, circuitus illi eadem revolventes locum non habent, quos maxime repellit aeterna vita sanctorum" (Ibid. XII, 19, PL 41, 369). Sobre el problema del tiempo en San Ajustín se pueden consultar losi siguienites trabajos: J. ChaIX-RuY, Le problème du temps dans les Confessions et dans la Cité de Dieu, "Giornale di Metafisica" IX (1954) 464-477; IDEM, La Cité de Dieu et la structure du temp's chez Saint Augustin, en "Augustinus Magister", Paris 1954, II, 923-931; IDEM, Saint Augustin: Temps et histoire, Paris 1956, XV +126 págss.; IDEM, La perception du temps chez Saint Augustin, en "Saint Augustin", cahier de la Nouvelle Journée, 17, pp. 17-93; RUDOLPH BerLinger, Le temps et l'homme chez Saint Augustin, en "L'année théologique augustinienne" XIII (1953) 260-279; V. CAPÁNAGA, Los ciclos cósmicos en La Ciudad de Dios, "La Ciudad: de Dios" 167 (1955): estudios sobre La Ciudad de Dios, II, 95-112; R. Flórez, El tema del tiempo en la filosofía de San Agustín, "La Ciudad de Dios" 166 (1954) 61-86; IDEM, Temporalidad y tiempo en la Ciudad de Dios. "La Ciudad de Dios" 167, I (1954) 169-185; RoBerT GILLET, Temps et exemplarisme chez Saint Augustin, en "Augustinus Magister", Paris 1954, II, 933-942; JEAN GuITTON, Le temps et l'éternité chez Plotin et chez Saint Augustin, Paris 1933, XXIV + 397 págıs.; H. MARRou, L'ambivalence du temps de l'histoire chez Saint Augustin (Conference Allbert-le-Grand), Paris 1950; J. Hubaux, Saint Augustin et la crise cyclique, "Augustinus Magisiter" Paris 1954, II, 943-950; Paolo Rossi, Le evoluzioni cicliche del mondo secondo Sant'Agostino, "Rivista di Filosofia Neo-scolastica", Supp. speciale XXIII (1931) 42-56. 
Agustín ${ }^{73}$. Dado que todas las cosas proceden de Dios, como ya hemos visto, la cuestión ahora no es discutir si los ángeles han sido creados, sino más bien cómo y cuándo fueron creados. La Escritura no trata claramente del problema, y San Agustín tiene que servirse de textos poco claros y de interpretaciones alegóricas para defender que los ángeles son las primeras creaturas salidas de la mano de Dios:

«Ubi de mundi constitutione sacrae Litterae loquuntur, non evidenter dicitur utrum vel quo ordine creati sint Angeli: sed si praetermissi non sunt, vel caeli nomine, ubi dictum est, «In principio fecit Deus caelum et terram» (Gen. 1, 1); vel potius lucis huius, de qua loquor, significati sunt. Non autem praetermissos esse hinc existimo, quod scriptum est requievisse Deum in septimo die $a b$ omnibus operibus suis quae fecit; cum liber ipse ita sit exorsus, «In principio fecit Deus caelum et terram»: ut ante caelum et terram nihil aliud fecisse videatur» 74 .

En primer lugar, pues, los ángeles no han sido silenciados en la narración de la creación, y si no aparecen claramente, es que han sido significados de forma alegórica cuando se dice que Dios creó la luz ${ }^{75}$. En otros pasajes de la Escritura, sin embargo, se dice que los ángeles fueron creados, lo cual, parece insinuar San Agustín, confirma la interpretación dada sobre el texto del Génesis:

«...quomodo Angeli praetermitterentur, tanquam non essent in operibus Dei, a quibus in die septimo requievit? Opus autem Dei esse Angelos, hic quidem etsi non praetermissum, non tamen evidenter expressum est: sed alibi hoc sancta Scriptura clarissima voce testatur. Nam et in hymno trium in camino virorum cum praedictum esset, «Benedicite, omnia opera Domini, Domino»; in exsecutione eorumdem operum, etiam Angeli nominati sunt (Dan. 3, 57-58). Et in Psalmo canitur: «Laudate Dominum de caelis, laudate eum in excelsis. Laudate eum, omnes Angeli eius; laudate eum, omnes Virtutes eius. Laudate eum sol et luna; laudate eum, omnes stellae et lumen. Laudate eum, caeli caelorum; et aquae quae super caelos sunt, laudent

73 "Nunc, quoniam de sanctae civitaltis exortu dicere institui, et prius quod ad sanctos angelos attinet dicendum putavi, quae huius civitatis et magna pars est, et eo beatior, quod nunquam peregrinata, quae hinc divina testimonia suppetant, quantum satis videbitur, Deo largienite, explicare curabo" (De Civ. Dei XI, 9, PL 41, 323).

74 Ibid. XI, 9, PL 41, 323

75 "Non mihi videtur ab operibus Dei absurda sententia, si cum lux illa prima facta est, Angeli creati intelliguntur" (Ibid. XI, 19, PL 41, 333). "...ut homo Dei tam eximiae divinaeque sapientiae, imo per eum Spiritus Dei in commemorandis operibus Dei, quae omnia sexto die dicit esse perfecta, nullo modo Angelos praetermisisse credaltur" (Ibid. XI, 33, PL 41, 347). 
nomen Domini. Quoniam ipse dixit, et facta sunt; ipse mandavit, et creata sunt (Ps. 148, 1-5)». Etiam hic apertissime a Deo factos esse Angelos divinitus dictum est, cum eis inter caetera caelestia commemoratis, infertur ad omnia, «Ipse dixit et facta sunt» 76 .

En cuanto al momento de su creación, si fueron creados antes o después de las demás creaturas, San Agustín defiende que fueron creados antes de todo lo demás ${ }^{77}$. No obstante, San Agustín no excluye otras posibles interpretaciones de la Sagrada Escritura con respecto a la creación de los ángeles ${ }^{78}$. Lo importante es que los ángeles fueron creados por Dios, que no son coeternos a $\mathrm{El}$, se interprete la luz de que habla el Génesis como referida a los ángeles o no:

«Dum tamen angelos sanctos in sublimibus sedibus, non quidem Deo coaeternos, sed tamen de sua sempiterna et vera felicitate securos et certos esse, nemo ambigat» ${ }^{79}$.

En realidad la comprensión de la luz como representación de

76 Ibid. XI, 9, PL 41, 324.

77 "Quis porro audebit opinari, post omnia ista quae sex diebus enum€rata sunt, Angelos factos? Sed et si quisquam ita desipit, redarguit istam vanitatem illa Scriptura paris auctoritatis, ubi Deus dicit, Quando facta sunt' sidera laudaverunt me voce magna omnes Angeli mei (Iob. 38, 7, sec. LXX). Iam ergo erant Angeli, quando facta sunt sidera. Facta sunt autem quarto die. Numquidnam ergo die tertio factos esse dicemus? Absit. In prompitu est enim, quid illo die factum sit. $A b$ aquis utique terra discreta est, et distinctas sui generis species duo ista elementa sumpserunt, et produxit terra quidquid ei radicibus inhaeret. Numquidnam secundo? Ne hoc quidem: thunc enim firmamentum factum est inter aquas superiores et inferiores, caelumque appellatum est; in quo firmamento facta sunt sidera quarto die. Nimirum ergo si ad istorum dierum opera Dei pertinent Angeli, ipsi sunt illa lux quae diei nomen accepit" (Ibid. XI, 9, PL 41, 324).

78 "Ne quis autem contendat, et dicat non sanctos Angelos esse significatos, in eo quod scriptium est, Fiat lux, et facta est lux; sed quamlibet lucem tunc primum factam esse corpoream aut opinetur, aut doceat: Angelos autem prius esse factos, non tantum ante firmamentum, quod inter aquas et aquas factum, appellatum est caelum, sed ante illud quod dictum estit, In principio fecit Deus caelum et terram: ante illud quod dictum est, In principio, non ita dictum tanquam primum hoc factum sit, cum ante fecerit Angelos: sed quia omnia in sapientia fecit, quod est Verbum eius, ett ipsum Stcriptura principium nominavit; sicut ipse in Evangelio Iudaeis quaerentibus quis esset, respondit se esse principium" (Ibid. XI, 32, PL 41, 345). "Quamquam nonnulli putaverint aquarum nomine significatos quodammodo populos Angelorum; et hoc esse quod dictum est, Fiat firmamentum inter aquam et aquam: ut supra firmamentum Angeli intelligantur, infra vero vel aquae istae visibiles, vel malorum angelorum multitudo, vel omnium hominum gentes. Quod si ita est, non illic apparet ubi facti sunt Angeli, sed ubi discreti" (Ibid. XI, 34, PL 41, 347). Cf. Confes. XIII, 15, 18 y 32, 47, PL 32, 852 y 865, donde Agustín parece sostener esta opinión, defendida por Orígenes, y Retraet. II, 6, 2, PL 32, 632, donde dice que fue una opinión un poco precipitada.

79 De Civ. Dei XI, 32, PL 41, 346. 
los ángeles es una interpretación basada no en la misma Escritura, sino en una serie de premisas filosófico-teológicas de Agustín. La identificación de la luz con los ángeles servía a San Agustín como punto de partida o más bien como ocasión para hablar de la iluminación de los ángeles, a lo cual invitaba el mismo parentesco lingüístico de las palabras.

Los ángeles, dice San Agustín, se llaman luz porque fueron iluminados y hechos partícipes de la luz del Verbo en la que fueron creados:

«Cum enim dixit Deus, «Fiat lux, et facta est lux»; si recte in hac luce creatio intelligitur Angelorum, profecto facti sunt participes lucis aeternae, quod est ipsa incommutabilis Sapientia Dei, per quam facta sunt omnia, quem dicimus unigenitum Dei Filium; ut ea luce illuminati, qua creati, fierent lux, et vocarentur dies participatione incommutabilis lucis et diei, quod est Verbum Dei, per quod et ipsi et omnia facta sunt. «Lumen quippe verum, quod illuminat omnem hominem venientem in hunc mundum» (Io. 1, 9), hoc illuminat et omnem angelum mundum, ut sit lux, non in se ipso, sed in Deo» 80 .

La iluminación no es un acto posterior a la creación, sino que es el acto de la creación misma. No fueron creados primero y después hechos partícipes de la luz del Verbo, sino que la participación de esa luz es lo que les constituye como seres creados:

«Quae cum ita sint, nullo modo quidem secundum aliquod temporis spatium prius erant illi spiritus tenebrae, quos Angelos dicimus; sed simul ut facti sunt, lux facti sunt: non tamen ita tantum creati, ut quoquo modo essent, et quoquo modo viverent; sed etiam illuminati, ut sapienter beateque viverent» 81 .

La creación y la iluminación son, por lo tanto, una sola y única acción de Dios. En el Verbo, por cuya participación fueron creados, conocen a Dios en su Trinidad inseparable y en su infinita perfección ${ }^{82}$. En esta luz del Verbo se conocen a sí mismos de una forma

80 Ibid. XI, 9, PL 41, 325.

81 Iibi.d. XI, 11, PL 41, 327.

82 "Illi quippe Angeli sancti non per verba sonantia Deum discunt; sed per ipsam praesentiam immutabilis veritiatis, hoc est, Verbum eius unigenitum: et ipsum Verbum et Patrem et eorum Spiritum sanctum; eamque esse inseparabilem Trinitatem, singulasque in ea personas esse unam substantiam; et tamen omnes non tres deos esse, sed unum Deum, ita noverunt, ut eis magis ista, quam nos ipsi nobis cogniti sumus" (Ibid. XI, 29, PL 41, 343). 
mucho más clara de como se conocen en sí mismos ${ }^{83}$, y conocen a las cosas mejor que en sí mismas, pues conocen a las creaturas en la sabiduría del artista, en la razón según la cual fueron hechas:

«Omnia haec aliter in Verbo Dei cognoscuntur ab Angelis, ubi habent causas rationesque suas, id est secundum quas facta sunt, incommutabiliter permanentes, aliter in se ipsis; illic clariore, hic obscuriore cognitione, velut artis atque operum» 84 .

En esta luz y en este conocimiento tenían los ángeles su felicidad: «illuminati, ut sapienter beateque viverent» ${ }^{85}$. En esta felicidad permanecen los ángeles buenos y ésta es la felicidad que perdieron los que se apartaron de Dios, aunque incluso antes del pecado no era tan grande como la de los ángeles buenos, porque no sabían si había de durar por siempre ${ }^{86}$. San Agustín admite una cierta diferencia entre la felicidad de los ángeles buenos y la de los malos antes de su caída: aquéllos estaban seguros de su perseverancia y por lo tanto de su bienaventuranza eterna, éstos no tenían tal presciencia, y por consiguiente su felicidad era menor ${ }^{87}$.

\section{Pecado de los Ángeles.}

Parte de los ángeles pecó rebelándose contra Dios, y esta rebelión les trajo la pérdida de su bienaventuranza y el castigo eterno:

83 "Ipsam quoque creatturam melius ibi, hoc est in sapientia Dei, tanquam in arte qua facta est, quam in ea ipsa sciunt: ac per hoc et se ipsos ibi melius quam in se ipsis, verumtamen et in se ipsis. Fácti sunt enim, et aliud sunt quam ille qui fecit" (Ibid. XI, 29, PL 41, 343).

84 Ibid. XI, 29, PL 41, 343. Vid. también el capítulo 7 de este mismo libro.

85 Ibid. XI, 11, PL 41, 327.

86 Ibid. XI, 11, PL 41, 327.

87 "Quocirca cuivis iam non difficulter occurrit utroque coniuncto effici beaititudinem, quam recto proposito intellectualis naitura desiderat; hoc est, ut bono incommutabili, quod Deus est, sine ulla molestia perfruatur, et in eo se in aeternum esse mansuram, nec ulla dubitatione cunctetur, nec ullo errore fallatur. Hanc habere Angelos lucis pia fide credimus; hane nec anitequam caderent, habuisse angelos peccatores, qui sua pravitate illa luce privati sunit, consequenti ratione colligimus; halbuisse tamen aliquam, etsi non praesciam beatitudinem, si vitam egerunt ante peccatum, profecto credendi sunt. Aut si 'durum videtur, quando facti sunt Angeli, alios credere ita factos ut non acciperent praescientiam vel perseverantiae vel casus sui, alios autem ita ut veritate certissima aeternitatem suae beatitudinis nossent; sed aequalis felicitatis omnes ab initio creati sunt, et ita fuerunt, donec isti qui nune mali sunt, ab illo bonitatis lumine sua voluntate cecidissent: procul dubio multo est durius nunc putare Angelos sanctos aeternae suae beatitatis incertos, et ipsos de semetipsis ignorare, quod nos de illis per scripturas sanctas nosse potuimus" (Ibid. XI, 13, PL 41, 328). Todo este capítulo está dedicado a desarrollar este tema. 
«Peccasse autem quosdam Angelos, et in huius mundi ima detrusos, qui eis velut carcer est, usque ad futuram in die iudicii ultimam damnationem, apostolus Petrus apertissime ostendit, dicens quod Deus angelis peccantibus non pepercerit, sed carceribus caliginis inferi retrudens tradiderit in iudicio puniendos reservari» 88 .

Así perdieron la felicidad de que gozaban, pues se apartaron de la luz en que habían sido creados, convirtiéndose en tinieblas. Según esto, San Agustín interpreta el versículo del Génesis: «Y vio Dios ser buena la luz, y la separó de las tinieblas; y a la luz llamó día, y a las tinieblas noche», diciendo que en esta luz están prefigurados los ángeles buenos, y en las tinieblas los malos, cuya caída Dios conocía en su eterna presciencia:

«Non mihi videtur ab operibus Dei absurda sententia, si cum lux illa prima facta est, Angeli creati intelliguntur, et inter sanctos Angelos et inmmundos fuisse discretum, ubi dictum est, «Et divisit Deus inter lucem et tenebras; et vocavit Deus lucem diem, et tenebras vocavit noctem». Solus quippe ille ista discernere potuit, qui potuit etiam priusquam caderent praescire casuros, et lumine privatos veritatis in tenebrosa superbia mansuros (...). Inter illam vero lucem, quae sancta societas Angelorum est illustratione veritatis intelligibiliter fulgens, et ei contrarias tenebras, id est malorum angelorum aversorum a luce iustitiae teterrimas mentes, ipse dividere potuit, cui etiam futurum, non naturae, sed volunțatis malum, occultum aut incertum esse non potuit» 89 .

San Agustín admite que el demonio gozó de un cierto tiempo de felicidad antes de su caída; otros admiten que se rebeló contra Dios inmediatamente después de su creación, basándose en las palabras del Evangelio: «El diablo era homicida desde el principio y no se mantuvo en la verdad» (Jo. 8, 44), y en aquellas otras de San Juan: «El diablo peca desde el principio» (I Jo. 3, 8) ${ }^{90}$. San Agustín no condena esta opinión, aunque no la comparta, dado que deja a salvo la creación de los ángeles malos por parte de Dios y la bondad de su naturaleza creada. Lo que no se puede admitir, y aquí entra de nuevo en polémica contra los maniqueos, es la afirmación de que el demonio es un principio malo coeterno a Dios ${ }^{91}$. Si se

88 Ibid. XI, 33, PL 41, 346.

89 Ibid. XI, 19, PL 41, 333. Cf́r. Ibid. XI, 33, PL 41, 346.

90 Ibi.d. XI, 13, PL 41, 329.

91 "Huic sententiae quisquis acquiescit, non cum illis haereticis sapit, id est Manichaeis, et si quae aliae pestes ita sentiunt, quod suam quamdam pro- 
dice que el diablo peca desde el principio, no quiere decir que peque desde el momento de su creación, sino desde el momento en que, ensoberbecido, se apartó de Dios. Pero mucho menos significa que el diablo sea el principio eterno y natural del mal, pues si es natural ya no es pecado:

«Illud etiam quod ait de diabolo Joannes, «Ab initio diabolus peccat»; non intelligunt, si naturale est, nullo modo esse peccatum» ${ }^{92}$.

Los deseos contrarios que separan a los ángeles buenos de los malos no son debidos a diversidad de naturaleza, sino a la diversidad de sus voluntades. Los ángeles malos, habiendo sido creados buenos, prefirieron su gloria a la Dios, torcieron su voluntad, y esto es lo que les hizo pecadores:

«Angelorum bonorum et malorum inter se contratios appetitus non naturis principiisque diversis, cum Deus omnium substantiarum bonus auctor et conditor utrosque creaverit, sed voluntatibus et cupiditatibus exstitisse, dubitare fas non est; dum alii constanter in communi omnibus bono, quod ipse illis Deus est, atque in eius aeternitate, veritate, charitate persistunt; alii sua potestate potius delectati, velut bonum suum sibi ipsi essent, a superiore communi omnium beatifico bono ad propria defluxerunt; et habentes elationis fastum pro excelsissima aeternitate, vanitatis astutiam pro certissima veritate, studia partium pro individua charitate, superbi, fallaces, invidi effecti sunt» ${ }^{93}$.

Su miseria consiste en no adherirse a Dios, bien inmutable, pues hasta tal punto es Dios el bien de los seres mudables, que sin El necesariamente son miserables, y siendo tan fácil la consecución de su felicidad, si no la logran es por su culpa, y por lo tanto el no adherirse a Dios es un vicio y un pecado de la naturaleza angélica, el cual sin embargo da testimonio de la bondad de la misma naturaleza, porque el vicio no puede existir por sí mismo ${ }^{94}$.

priam tanquam ex adverso quodam principio diabolus habeat naturam mali: qui tanta vanitate desipiunt, ut cum verba ista evangelica in auctoritate nobiscum habeant, no nattendant non dixisse Dominum, A veritate alienus fuit; sed In veritate non stetit: ubi a veritate lapsum intelligi voluit: in qua utique si stetisset, eius particeps factus, beatus cum sanctis Angelis permaneret" (Ibid. $\mathrm{XI}, 13$, PL 41, 329).

92 Ibid. XI, 15, PL 41, 330. Cf. el resto del capítulo, hasta el final.

93 Iibid. XII, 1, 2, PL 41, 349.

94 Ibid. XII, 1, 3, PL 41, 349. El argumento de San Agustín es clarísimo e irrefutable, y concluye con las palabras siguientes: "Quapropter etiam vitio malorum angelorum, quo non adhaerent Deo, quoniam omne vitium naturae 
Con su orgullosa rebelión los ángeles malos se apartaron de Dios, y por esto mismo prefirieron la miseria de su soberbia a la felicidad de la adhesión a Dios:

«Proinde causa beatitudinis Angelorum bonorum ea verissima reperitur, quod ei adhaerent qui summe est. Cum vero causa miseriae malorum angelorum quaeritur, ea merito occurrit, quod ab illo qui summe est aversi, ad se ipsos conversi sunt, qui non summe sunt: et hoc vitium quid aliud quam superbia nuncupatur? «Initium quippe omnis peccati superbia» (Eccli. 10, 15). Noluerunt ergo ad illum custodire fortitudinem suam: et qui magis essent, si ei qui summe est adhaererent; se illi praeferendo, id quod minus est praetulerunt. Hic primus defectus et prima inopia primumque vitium eius naturae, quae ita creata est, ut nec summe esset, et tamen ad beatitudinem habendam, eo qui summe est frui posset, a quo aversa, non quidem nulla, sed tamen minus esset, atque ob hoc misera fieret» ${ }^{95}$.

Nada les obligaba a una tal elección, no existe ninguna causa eficiente de su mala voluntad; su defección constituye su mala voluntad, por el mismo hecho de apartarse del sumo bien. Su elección fue libre, su caída no es necesaria, sino fruto del mal uso de su libertad:

«Eoque sunt isti ab illorum societate discreti, quod hi in eadem voluntate bona manserunt, illi ab ea deficiendo mutati sunt, mala scilicet voluntate, hoc ipso quod a bona defecerunt: a qua non defecissent, si utique noluissent» ${ }^{96}$.

Si unos cayeron y otros perseveraron en la buena voluntad, esto se debe, en definitiva, a la gracia de Dios, por la cual los ángeles buenos optaron por seguir unidos a su Creador ${ }^{97}$.

La deserción de los ángeles malos les acarreó la muerte, no una muerte completa, sino la muerte de los que, siguiendo en la existencia, se ven privados de la presencia vivificante de Dios:

nocet, satis manifestatur Deum tam bonam eorum creasse naturam, cui noxium sit non esse cum Deo". Ya hablamos de este tema al tratar del origen del mal, pero nos ha parecido bien recordarlo aquí de nuevo, en su propio contexto.

95 Ibid. XII, 6, PL 41, 353.

96 Ibid. XII, 9, 1, PL 41, 356.

97. "Isti autem, qui cum boni creati essent, tamen mali sunt, mala propria voluntate, quam bona natura non fecit, nisi cum a bono sponte defecit, ut mali causa non sit bonum, sed defectus a bono, aut minorem acceperunt amoris divini gratiam, quam illis qui in eadem perstiterunt; aut si utrique boni aequaliter creati sunt, istis mala voluntate cadentibus, illi amplius adiuti, ad eam beatitudinis plenitudinem, unde se nunquam casuros certissimi fierent pervenerunit." (Ib:d. XII, 9, 2, PL 41, 357). 
«Sicut etiam desertores angeli, licet quemdam modum mortui sint peccando; quia fontem vitae deseruerunt qui Deus est, quem potando, sapienter beateque poterant vivere: tamen non sic mori potuerunt ut omnino desisterent vivere atque sentire; quoniam immortales creati sunt: atque ita in secundam mortem post ultimum praecipitabuntur iudicium, ut nec illic vita careant; quandoquidem etiam sensu cum in doloribus futuri sunt, non carebunt» 98 .

En esta muerte permanecerán por toda la eternidad, apartados de la visión de Dios, en justo castigo de su soberbia y de su separación voluntaria del sumo bien.

Con la rebelión de los ángeles malos y la consiguiente división entre los ángeles buenos y los malos o demonios, surgen las dos ciudades opuestas, la una basada en el amor de Dios, la otra en el amor propio. Pero los ángeles malos, envidiosos de la suerte del hombre, tratarán de hacerle caer de su feliz estado de sumisión para engrosar las filas de su sociedad enemiga de Dios:

«Postea vero quam superbus ille angelus, ac per hoc invidus, per eamdem superbiam a Deo ad semetipsum conversus, quodam quasi tyrannico fastu gaudere subditis, quam esse subditus eligens, de spirituali paradiso cedit... malesuada versutia in hominis sensus serpere affectans, cui utique stanti, quoniam ipse ceciderat, invidebat, colubrum in paradiso corporali... animal scilicet lubricum et tortuosis anfractibus mobile, operi suo congruum, per quem loqueretur, elegit» 99 .

El hombre cayó en las redes del tentador y de esta forma surgió también entre los hombres la ciudad terrena, opuesta a la ciudad de Dios ${ }^{100}$.

\section{LA CREACIÓN DEL HOMBRE.}

Pero antes de la caída del hombre debemos estudiar las cuestiones referentes a su creación y a su estado primitivo en el paraíso. Habiendo probado que todos los seres proceden de Dios, San Agustín no se detiene mucho a demostrar que también el

98 Iibid. XIII, 24, 6, PL 41, 402.

99 Iibid. XIV, 11, 2, PL 41, 419.

100 "Cuius pars quae coniungenda immortalibus Angelis ex immortalibus hominibus congregatur, et nunc mortaliter peregrinatur in terris, vel in eis qui morte obierunt, secretis animarum receptaculis sedibusque requiescit, eodem Deo creante, quemadmodum exorta sit, sicuit de Angelis dictum est, iam video esse dicendum" (Ibid. XII, 9, 2, PL 41, 357). 
hombre ha sido creado. Más bien, pasa en seguida a discutir algunas cuestiones sobre el tiempo de su creación.

«Alii, sicut de ipso mundo crediderunt, semper fuisse homines opinantur» ${ }^{101}$. A esta creencia de algunos filósofos, como Apuleyo, el cual dice: «Uno a uno son mortales, pero en su conjunto son perpetuos», San Agustín opone la historia de la humanidad, que nos presenta el progreso de la humanidad, describiendo su evolución y narrando las invenciones y descubrimientos que han hecho avanzar la cultura ${ }^{102}$.

A este error, dice San Agustín, son inducidos por una falsa cronología de la humanidad, que atribuye al género humano muchos miles de años de existencia, cuando la Sagrada Escritura calcula sólo unos seis mil años desde la creación a nuestros días. $Y$ ya hemos visto la respuesta de Agustín a los que preguntan por qué la creación del hombre ha sido tan tarde: con respecto a la eternidad divina esta pregunta no tiene razón de ser.

Dios creó al hombre en el tiempo, sin que esto signifique un cambio en su voluntad, como ya hemos visto:

«...et hominem quem nunquam ante fecerat fecit in tempore, non tamen novo et repentino, sed immutabili aeternoque consilio» ${ }^{103}$.

La sabiduría y perfección de Dios se muestran maravillosamente en la creación del hombre; Dios en efecto hizo que todo el género humano se multiplicase a partir de un solo hombre, para facilitar la sociabilidad, el amor y la concordia entre los diversos individuos:

«...non est arduum videre multo fuisse melius quod factum est, ut ex uno homine quem primum condidit, multiplicaret genus humanum, quam si id inchoasset a pluribus. ...unum ac singulum creavit, non utique solum sine humana societate deserendum, sed ut eo modo vehementius ei commendaretur ipsius societatis unitas vinculumque concordiae, si non tantum inter se naturae similitudine, verum etiam cognationis affectu homines necterentur; quando

101 Ibid. XII, 10, 1, PL 41, 357.

102 Ibi.d. XII, 10, 1, PL 41, 358.

108 Ibid. XII, 14, PL 41, 362. "...et hominem quem nunquam fecerat, ex aliquo tempore primum facere voluisise, nec consilium voluntatemque mutasse" (Ibid., loc. cit., al final del capítulo). "...ita hominem nunquam antea fuisse, et ex quodam tempore primum hominem creatum esse dubitare non debeo" (Ibid. XII, 15, 1, PL 41, 363). 
nec ipsam quidem feminam copulandam viro, sicut ipsum creare illi placuit, sed ex ipso, ut omne ex homine uno diffunderetur genus humanum» 104.

Incluso la primera mujer es sacada del costado del primer hombre, para encomendar más profundamente la unión entre ambos sexos y entre todos los hombres:

«...cui populo esset huius rei consideratio profutura, quod ex uno homine Deus ad commendandum hominibus, quam ei grata sit etiam in pluribus unitas, genus instituisset humanum» 105 .

Dios creó al hombre de la nada, y lo creó a su imagen y semejanza, como dice el Génesis:

«Fecit ergo Deus hominem ad imaginem suam. Talem quippe illi animam creavit, qua per rationem atque intelligentiam omnibus esset praestantior animalibus terrestribus et natatilibus et volatilibus, quae mentem huiusmodi non haberent» 106 .

El tema del hombre hecho a imagen de Dios tiene una rica literatura en los Padres, y San Agustín, en concreto, la desarrollará abundantemente en sus escritos, llevándola a un nivel de gran perfección y riqueza intelectual y espiritual. Al principio tuvo que superar la dificultad maniquea de entender a Dios como un ser corporal ${ }^{107}$; si el hombre está hecho a imagen de Dios, decían, entonces Dios tiene un cuerpo como nosotros; superada la dificultad

104 Iibid. XII, 21, PL 41, 372. "Ex uno quippe homine, quem primum Deus condidit, genus humanum sumpsit exordium, secundum sanctae Scripturae fidem" (Ibid. X́II, 9, 2, PL" 41, 357). "Tu cives civibus, gentes gentibus, et prorsus homines primorum parentum recordatione, non societate tantum, sed quadam etiam fraternitate coniungis" (De mor. Eccl. cath. I, 30, 63, PL 32, 1336).

${ }_{105}$ De Civ. Dei XII ,22, PL 41, 373. "Diximus iam superioribus libris ad humanum genus, non solum naturae similitudine sociandum, verum etiam quadam cognationis necessitudine in unitatem concordem pacis vinculo colligandum, ex homine uno Deum voluisse homines instituere" (Ibid. XIV, 1, PL 41, 403). "In quibus iterrenis praecipuus ab illo ad eius imaginem homo propter eam causam, 'quam dixi, et si qua forte alia maior latet, factus est unus, sed non relictus est solus. Nihil enim est quam hoc genus itam dicordiosum vitio, tam sociale natura. Neque commodius contra vitium discordiae vel cavendum ne exsisteret, vel sanandum cum exstitisselt, natura loqueretur humana, quam recordationem illius parentis, quem propterea Deus creare voluit unum, de quo multitudo propagaretur, ut hac admonitione etiam in multis concor's unitas servaretur. Quod vero femina illi ex eius latere facta est, etiam hinc satis significatum est quam chara mariti et uxoris debeat esse coniunctio" (Ibid. XII, 27, 1, PI 41, 376).

106. Ibid. XII, 23, PL 41, 373.

107 Confes. III, 7, 12, PL 32, 688, 
gracias al espiritualismo de los platónicos y a la interpretación espiritual de la Sagrada Escritura, recibida de San Ambrosio, Agustín puede concebir rectamente la imagen de Dios en el hombre y elaborar todo un cuerpo de doctrina teológico-espiritual sobre este tema.

Por lo dicho se ve que para San Agustín la imagen de Dios en el hombre radica en su parte superior, en el alma o espíritu:

"Cum enim homo rectissime intelligatur, vel si hoc non potest, saltem credatur factus ad imaginem Dei; profecto ea sui parte est propinquior superiori Deo, qua superat inferiores suas, quas etiam cum pecoribus communes habet» 108 .

Si se dice que el hombre fue hecho a imagen de Dios, no quiere decir que sea todo el hombre: es un modo de hablar de la Escritura, la cual dice también que el hombre ha de volver al polvo, siendo así que sólo su cuerpo se convertirá en polvo:

«Sed intelligendum est, secundum quid dicatur homo ad imaginem Dei, et homo terra atque iturus in terram. Illud enim secundum animam rationalem dicitur, qualem Deus insufflando, vel si commodius dicitur, inspirando indidit homini, id est hominis corpori: hoc autem secundum corpus, qualem hominem Deus finxit ex pulvere, cui data est anima, ut fieret corpus animale, id est homo in animam viventem» 109.

Está claro, por consiguiente, que la imagen de Dios radica en la parte espiritual del hombre. En el De Trinitate San Agustín busca los vestigios de la Trinidad en el hombre, pero estos vestigios no constituyen propiamente la imagen de Dios, puesto que en un menor grado se pueden encontrar también en las creaturas irracionales. El hombre es imagen de Dios por su capacidad de recordar, entender y amar a Dios ${ }^{110}$. Con el pecado la imagen queda rebajada y disminuída, de un plano consciencial a un nivel puramente presencial. Por lo tanto toda la ascética y espiritualidad cristianas pueden resumirse en estas palabras: devolver a la imagen de Dios en nosotros su esplendor originario, perdido por la desobediencia de los primeros padres ${ }^{111}$.

108 De Civ. Dei XI, 2, PL 41, 318.

109 Ibid. XIII, 24, 2, PL 41, 400.

110 De Trin. XIV, 12, 15, PL 42, 1048.

111 Nos hemos salido un poco de los límites de nuestro trabajo, pero nos ha parecido oportuno para dar una breve visión general de la doctrina agusti- 
Formó, pues, Dios al hombre del polvo de la tierra y le infundió un soplo de vida. Este soplo indica el alma, por medio de la cual el hombre es viviente espiritual, no la infusión del Espíritu Santo, como dicen algunos, pretendiendo que ya antes había creado el alma. Lo cual no quiere decir que el alma, infundida por un soplo de la boca de Dios, sea de la misma naturaleza de Dios; el alma procede de la boca de Dios, pero no como una emanación suya, sino como un nuevo ser creado de la nada, lo mismo que todas las creaturas ${ }^{112}$.

Dios creó al hombre con una voluntad recta y buena, capaz de seguir el bien y de someterse a su Creador ${ }^{113}$. Si después comete el mal, esto no es debido a su divino Autor, sino a su soberbia que le hace separarse de El.

\section{EL ESTADO PRIMITIVO DEL HOMBRE.}

Esto nos lleva a tratar del estado primitivo del hombre antes

niana sobre la imagen de Dios en el hombre, completando así las breves indicaciones que se encuentran en estos libros de "La Ciudad de Dios". La obra fundamental para esite tema es el tratado De Trinitate. Para una ampliación de conocimientos sobre la cuestión, cf. JoSÉ MORÁn, Acción y contemplación en el libro XII del De Trinitate, en "Studia Patristica" IX, Berlín 1966, pp. 451-468; IDEM, Sant'Agostino e la sua spiritualità, parte II (ad usum privatum), Roma 1967-1968, pp. 269-285; JoHN E. SULLIVAN, The image of God: The doctrine of Saint Augustine and its influence, The Priory Press, Dubuque, Iowa 1963, XVIII + 356 págs.

112 "Unde et illud' parum considerate quibusdam visum est, in eo quod legitur, Inspiravit Deus in faciem eius spiritum vitae, et factus est homo in animam viventem, non tunc animam primo homini datam, sed eam quae iam inerat, Spiritu Sancto vivificatam... Hune igitur formatum hominem de terrae pulvere, sive limo (erat enim pulvis humectus); hunc, inquam, ut expressius dicam, sicut Scriptura locuta est, pulverem de terra, animale corpus factum esse docet Apostolus cum animam accepit. Et factus est iste homo in animam viven"tem, id' est, formatus iste pulvis factus esit in animam viventem" (De Civ. Dei XIII, 24, 1, PL 41,398). "Sed enim Dei flatus, inquiunt, Dei ore exisse intelligitur, quem si animam crediderimus, consequens erit ut eiusdem fateamur esse substantiae, paremque illius Sapientiae, quae dicit: Ego ex ore Altissimi prodivi. Non quidem dixit Sapientia ore Dei efflatam se fuisse, sed ex eius ore prodisse. Sicut autem nos possumus, non de nostra natura qua homines sumus, sed de isto aere circumfuso, quem spirando ac respirando ducimus ac deducimus, flatum facere cum sufflamus: ita omnipotens Deus, non de sua natura, neque de subiacenti creatura, sed etiam de nihilo potuit facere flatum, quem corpori hominis inserendo inspirasse vel insufflasse convenientissime dictus est, incorporeus incorporeum, sed immutabilis mutabilem; quia non creatus creatum" (Ibid. XIII, 24, 5, PL 41, 402). Todo este largo capítulo está dedicado a discutir cómo se debe interpretar este soplo de Dios al hombre.

113 "Fecit itaque Deus, sicut scriptum est, hominem rectum: ac per hoc voluntatis bonae. Non enim rectus esset, bonam non habens volunitatem. Bona igitur voluntas opus est Dei : cum ea quippe ab illo factus est homo" (Ibid. XIV, 11, 1, PL 41, 418). "Deus enim creavit hominem rectum, naturarum auctor, non utique vitiorum" (Ibid. XIII, 14, PL 41,386). 
del pecado, el estado en que fue creado por Dios y en el cual fue colocado en el paraíso.

El hombre vivía en un paríso de felicidad, un paraíso espiritual y corporal, en paz interior de su alma humilde, y en la tranquilidad exterior de una naturaleza benigna y pronta a proveer a todos sus deseos y necesidades:

«Vivebat itaque homo secundum Deum in paradiso, et corporali et spirituali. Neque enim erat paradisus corporalis propter corporis bona, et propter mentis non erat spiritualis; aut vero erat spiritualis quo per interiores, et non erat corporalis quo per exteriores sensus homo frueretur. Erat plane utrumque propter utrumque. ...in paradiso corporali, ubi cum duobus illis hominibus masculo et femina animalia etiam terrestria caetera subdita et innoxia versabantur» 114 .

En este paraíso el hombre vivía tranquilo, alabando a su Creador, sin la preocupación de estar sujeto a un complicado código de leyes morales: sólo un precepto había recibido de Dios, que quería encomendarle la obediencia y sujeción a su Creador, fuente de su felicidad ${ }^{115}$. El hombre no tenía otros deseos que los que podía satisfacer según los medios recibidos por Dios; por eso no conocía la insatisfacción ni la infelicidad de la impotencia, pues aunque no podía todas las cosas, no deseaba las que no podía conseguir, y así podía todo lo que deseaba ${ }^{116}$.

El primer hombre era feliz en el paraíso, con una felicidad menor que la de los bienaventurados en el cielo, porque éstos están seguros de la eternidad de su gloria, pero felicidad al fin y al cabo mucho mayor de la que gozan los justos en esta tierra ${ }^{117}$. La felici-

114 Ibid. XIV, 11, 2, PL 41, 419.

115 "...qui (Deus) in paradiso constituerat, qui rerum omnium copiam salutisque praestiterat, qui praeceptis nec pluribus nec grandibus nec difficilibus: oneraverat, sed uno brevissimo atque levissimo ad obedientiae salubritaitem adminiculaverat, quo eam creaturam, cui libera servitus expediret, se esse Dominum commonebat" (Iibid. XIV, 15, 1, PI 41, 423).

116 "In paradiso enim etiamsi non omnia poterat ante peccatum, quidquid tamen non poterait, non volebat; et ideo potterat omnia quae volebat" (Ibid. XIV, 15, 2, PL 41, 423).

117 "Quantum itaque pertinet ad delectationem praesentis boni, beatior erat primus homo in paradiso, quam quilibet iustus in hac infirmitate mortali: quantum autem ad spem futuri, beatior quilibet in quibuslibet cruciatibus corporis, cui non opinione, sed certa veritate manifestum est, sine fine se habiturum omni molestia carentem societatem Angelorum in participatione summi Dei, quam erat ille homo sui casus incertus in magna illa felicitate paradisi" (Ibid. $\mathrm{XI}, 12, \mathrm{PL} 41,328$ ). 
dad de que gozaban, mermada por la ignorancia de su perpetuidad, se convertiría en felicidad eterna y completa si observaban el precepto del Señor:

«Hominem vero, cuius naturam quodammodo mediam inter Angelos bestiasque condebat, ut, si Creatori suo tanquam vero Domino subditus praeceptum eius pia obedientia custodiret, in consortium transiret angelicum, sine morte media beatam immortalitatem absque ullo termino consecutus; si autem Dominum Deum suum libera voluntate superbe atque inobedienter usus offenderet, morti addictus bestialiter viveret, libidinis servus aeternoque post mortem supplicio destinatus» ${ }^{118}$.

La felicidad de los primeros hombres gozaba de la inmunidad de la muerte: si continuaban fieles al Señor, pasarían, una vez cumplido su período terreno, a la vida celestial sin sufrir la muerte y la descomposición corporal:

«Non enim eo modo quo Angelos, condiderat Deus homines; ut etiam si peccassent, mori omnino non possent: sed ita ut perfunctos obedientiae munere sine interventu mortis angelica immortalitas et beata aeternitas seque. retur; inobedientes autem mors plecteret damnatione iustissima» 119 .

$Y$ esta inmunidad de la muerte se transmitiría a sus descendientes, junto con todos los demás dones corporales, si no hubiesen pecado:

«Quapropter fatendum est primos quidem homines ita fuisse institutos ut, si non peccassent, nullum mortis experirentur genus: sed eosdem primos peccatores ita fuisse morte mulctatos, ut etiam quidquid de eorum stirpe esset exortum, eidem poenae teneretur obnoxium» 120 .

El cuerpo de los primeros padres fue creado con el don de la inmortalidad y de la incorruptibilidad. Entonces el cuerpo no era un obstáculo a la felicidad, como lo es ahora, sino más bien un

118 Ibid. XII, 21, PL 41, 372.

119 Ibid. XIII, 1, PL 41, 377. "Hanc enim (mortem) primi homines, nisi peccassent, perpessi utique non fuissent" (Ibid. XIII, 3, PL 41, 37.8). "Nunc de corporibus primorum hominum quod instituimus explicemus: quoniam nec mors ista, quae bona perhibetur bonis, nec tantum paucis intelligentibus sive credentibus, sed omnibus nota est, qua fit animae a corpore separatio, qua certe corpus animantis, quod evidenter vivebat, evidenter emoritur, eis potuisset accidere, nisi peccati meritum sequeretur" (Ibid. XIII, 19, PL 41, 392).

120 Ibid. XIII, 3, PL 41, 378. 
componente más de esa felicidad, de la cual participaba junto con el alma:

«Non ergo ad beatitudinem consequendam omnia fugienda sunt corpora; sed corruptibilia, molesta, gravia, moribunda; non qualia fecit primis hominibus bonitas Dei, sed qualia esse compulit poena peccati» 121 .

Sin embargo, no gozaba de la incorruptibilidad perfecta, de la eterna inmortalidad de los cuerpos resucitados, los cuales gozarán de una perfección mucho más elevada que la de los cuerpos de los primeros padres. El cuerpo de los bienaventurados después de la resurrección, en efecto:

«Non solum enim non erit tale, quale nunc est in quavis optima valetudine; sed nec tale quidem quale fuit in primis hominibus ante peccatum. Qui licet morituri non essent, nisi peccassent; alimentis tamen ut homines utebantur, nondum spiritualia, sed adhuc animalia corpora terrena gestantes» 122

$\mathrm{Su}$ cuerpo por lo tanto aunque no envejeciese ni estuviese condenado a la muerte, era todavía un cuerpo animal, no espiritual, como lo será una vez resucitado. El cuerpo espiritual le estaba reservado como premio a su obediencia:

«Primus autem homo de terra terrenus, in animam viventem factus est, non in spiritum vivificantem, quod ei per obedientiae meritum servabatur. Ideo corpus eius, quod cibo ac potu egebat, ne fame afficeretur ac siti, et non immortalitate illa absoluta atque indissolubili, sed ligno vitae a mortis necessitate prohibebatur, atque in iuventutis flore tenebatur, non spirituale sed

121 Ibi.d. XIII, 17, 2, PL 41, 390.

122 Ibid. XIII, 20, PL 41, 393. San Agustín ve en el árbol de la vida que estaba en el paraíso una especie de sacramento o alimento espiritual, que conservaiba a los primeros padres en su incorruptibilidad, en su perenne juventud, hasta que pasasen definitivamente a la inmortalidad perfecta; efectivamente, a continuación del texto citado, dice lo siguiente: "Quae licet senio non veterascerent, ut necessitate perducerentur ad mortem (qui status eis de ligno vitae, quod in medio paradiso cum arbore vetita simul erat, mirabili Dei gratia praestabatur)... Alebantur ergo aliis quae sumebanit, ne animalia corpora molestiae aliquid esuriendo ac sitiendo sentirent: de ligno autem vitae propterea gustabantur, ne mors eis undecumque subreperet, vel senectute confecta decursis temporum spatiis interirent: tanquam caetera essent alimento, illud sacramento; ut sic fuisse accipiatur lignum vitae in paradiso corporali, sicut in spirituali, hoc est intelligibili paradiso, Sapientia Dei, de qua sicriptum est, Lignum vitae est amplectentibus eam" (Ibid. XIII, 20, PL 41, 394). C.f. tamibién Ibid. XIII, 22-23, PL 41, 395-398. 
animale fuisse, non dubium est: nequaquam tamen moriturum, nisi in Dei praedicentis minantisque sententiam delinquendo corruisset» ${ }^{123}$.

El hombre en el paraíso no conocía tampoco las pasiones del ánimo, el temor, el dolor, la tristeza, que nos afligen en el estado actual de pecado:

«Sed utrum primus homo vel primi homines (duorum erat quippe coniugium) habebant istos affectus in corpore animali ante peccatum, quales in corpore spirituali non habebimus, omni purgato finitoque peccato, non immerito quaeritur. Si enim habebant, quomodo erant beati in illo memorabili beatitudinis loco, id est paradiso? Quis tandem absolute dici beatus potest, qui timore afficitur vel dolore? Quid autem timere aut dolere poterant illi homines in tantorum tanta affluentia bonorum, ubi nec mors metuebatur, nec ulla corporis mala valetudo; nec aberat quidquam, quod bona voluntas adipisceretur, nec inerat quod carnem animumve hominis feliciter viventis offenderet? Amor erat impertubatus in Deum atque inter se coniugum fida et sincera societate viventium, et ex hoc amore grande gaudium, non desinente quod amabatur ad fruendum. Erat derivatio tranquilla peccati, qua manente nullum omnino aliunde malum quod contristaret, irruebat» 124 .

En ese estado de felicidad, sin verse afligidos por el dolor y por la muerte, sin tener nada que temer, vivirían todos los descendientes de Adán y Eva, hechos partícipes de su obediencia, como ahora lo somos de su desobediencia:

«Quam igitur felices erant primi homines, et nullis agitabantur perturbationibus animorum, nullis corporum laedebantur incommodis: tam felix universa societas esset humana, si nec illi malum, quod etiam in posteros traiecerunt, nec quisquam ex eorum stirpe iniquitatem committeret, quae damnationem reciperet: atque ista permanente felicitate, donec per illam benedictionem, qua dictum est, «Crescite et multiplicamini» (Gen. 1, 28), praedestinatorum sanctorum numerus compleretur, alia major daretur, quae beatissimis Angelis data est: ubi iam esset certa securitas peccaturum neminem, neminemque moriturum: et talis esset vita sanctorum, post nullum laboris, doloris, mortis experimentum, qualis erit post haec omnia in incorruptione corporum reddita resurrectione mortuorum» 125 .

Los primeros hombres vivían en el paraíso libres de la pasión de la libido; estando su voluntad sometida a Dios, también la parte

123 Ibid. XIII, 23, 1, PL 41, 396. Cf. todo este capítulo, en el que repite continuamente estas ideas; igualmente XIII, 24, 6, PL 41, 406.

124 Ibid. XIV, 10, PL 41, 417.

125 Ibid. XIV, 10, PL 41, 417. 
inferior de su ser estaba sometida a la superior, al espíritu, colaborando con él en la alabanza al Creador y participando de la tranquila felicidad del paraíso. La sexualidad estaba bajo el control de la voluntad, y los órganos genitales obedecían y se movían a las órdenes de la voluntad, como obedecen los brazos y las otras partes del cuerpo de moción voluntaria. Estas partes no eran entonces vergonzosas, como las consideramos en el estado actual, pues no se había desencadenado la libido que las había de sustraer al poder de la voluntad:

«Merito huius libidinis maxime pudet, merito et ipsa membra, quae suo quodam, ut ita dixerim, iure, non omnimodo ad arbitrium nostrum movet, aut non movet, pudenda dicuntur, quod ante peccatum hominis non fuerunt. Nam sicut scriptum est, «Nudi erant, et non confundebantur» (Gen. 2, 25); non quod eis nuditas esset incognita, sed turpis nuditas nondum erat; quia nondum libido membra illa praeter arbitrium commovebat, nondum ad hominis inobedientiam redarguendam sua inobedientia caro quodammodo testimonium perhibebat» 126 .

Hoy día nos resulta difícil hacernos a la idea de que entonces se pudiese realizar el acto de la generación sin esta libido que en la actual situación nos invade. Pero que esto sea posible nos lo dan a entender esas palabras del Señor a los primeros padres: «Creced y multiplicaos y llenad la tierra». Y no se deben entender espiritualmente, diciendo que se refieren a los frutos de la virtud y santidad de Adán y Eva, como algunos dicen para responder a esta dificultad, sino realmente en sentido material y físico de la procreación de los hijos ${ }^{127}$. El acto conyugal y la generación de los hijos entraban dentro de los planes de Dios, son dones del matrimonio, concedidos y bendecidos por Dios. Dios creó al hombre «varón y mujer, macho y hembra», y el sexo lleva en sí siempre algo carnal; por lo tanto esto era querido por Dios, creador bueno de todas las cosas ${ }^{128}$.

Sin embargo esta unión se realizaría sin los arrebatos de la

126 Ibid. XIV, 17, PL 41, 425. "Hae inquam partes in paradiso ante peccatum vitiosae non erant. Non enim contra rectam voluntatem ad aliquid movebantur, unde necesse esset eas rationis tanquam frenis regentibus absitinere" (Ibid. XIV, 19, PL 41, 427).

127 De Civ. Dei XIV, 21, PL 41, 429. Sin embargo en otros lugares admite también la interpretación espiritual, aunque no excluya la carnal: Cf. De Gen. contra Manich. I, 19, 30. II, 11, 15, PL 34, 187 y 204; Confes. XIII, 24, 35-37, PL 32, 860 .

128 De Civ. Dei XIV, 22, PL 41, 429. 
pasión de la libido, sino con perfecto control por parte de la voluntad:

«Et ideo illae nuptiae dignae felicitati paradisi, si peccatum non fuisset, et diligendam prolem gignerent, et pudendam libidinem non haberent. Sed quomodo id fieri posset, nune non est quo demonstretur exemplo» 129.

En un estado de felicidad como el que existía en el paraíso, no podemos pensar que se diese esta esclavitud de la libido por la cual el hombre se ve incapaz de dominar su cuerpo y sus pasiones sexuales:

«In tanta facilitate rerum et felicitate hominum, absit ut suspicemur non potuisse prolem seri sine libidinis morbo: sed eo voluntatis nutu moverentur illa membra quo caetera, et sine ardoris illecebroso stimulo cum tranquillitate animi et corporis nulla corruptione integritatis infunderetur gremio maritus uxoris. Neque enim quia experientia non potest probari, ideo credendum non est; quando illas corporis partes non ageret turbidus calor, sed spontanea potestas, sicut opus esset, adhiberet» 130 .

Con estas características se hubiese realizado el acto conyugal si los primeros padres no hubiesen pecado. Pero de hecho el pecado sobrevino antes de haber cohabitado, pues está claro en la Escritura que los hijos de Adán y Eva fueron engendrados y nacieron fuera del paraíso:

«Nam cum id quod dico, nec ipsi experti fuerint qui experiri potuerunt (quoniam praeoccupante peccato exsilium de paradiso ante meruerunt quam sibi in opere serendae propaginis tranquillo arbitrio convenirent)...»131.

129 Ibid. XIV, 23, 2, PL 41, 430. Cf. todo este capítulo. "Seminaret igitur prolem vir, susciperet femina genitalibus membris quando id opus esset, et quanitum opus esset, voluntate motis, non libidine concitatis... Sic ergo et ipse homo potuit obedientiam etiam inferiorum habere membrorum, quam sua inobedientia perdidit. Neque enim Deo difficile fuit sic illum condere, ut in eius carne etiam illud nonnisi eius voluntate moveretur, quod nunc nisi libidine non movetur... Cum itaque corpus etiam nunc quibusdam, licet in carne corruptibili hanc aerumnosam ducentibus vitam, ita in plerisque motionibus et affectionibus extra usitatum naturae modum mirabiliter serviat; quid causae esit, ut non credamus ante pecatum inobedientiae corruptionisque supplicium, ad propagandam prolem sine ulla ilibidine servire voluntati humanae humana memibra potuisse?" (Ibi.d. XIV, 24, 1-2, PL 41, 432).

130 Ibid. XIV, 26, PL 41, 434.

131 Ilbid. XIV, 26, PL 41, 434. “...nec in paradiso futuros fuisse, sed foris, sicut et factum est. Nam postteaquam inde dimissi sunt, ad gignendos filios coierunt, eosque genuerunt" (Ibild. XIV, 21, PL 41, 429). Cf. De Gen. ad lit. IX, $3,6, \mathrm{PL} 34,395$. 
Este era el estado del hombre en el paraíso, estado que se habría prolongado en los descendientes de Adán y Eva si no hubieran pecado, si no hubieran cometido el pecado de soberbia y desobediencia. En este texto, con el cual cerramos esta parte, San Agustín resume brevemente sus ideas sobre la situación del hombre en el paraíso:

«Vivebat itaque homo in paradiso sicut volebat, quamdiu hoc volebat quod Deus iusserat: vivebat fruens Deo, ex quo bono erat bonus: vivebat sine ulla egestate, ita semper vivere habens in potestate. Cibus aderat, ne esuriret; potus, ne sitiret; lignum vitae, ne illum senecta dissolveret: Nihil corruptionis in corpore vel ex corpore ullas molestias ullis eius sensibus ingerebat. Nullus intrinsecus morbus, nullus ictus metuebatur extrinsecus. Summa in carne sanitas, in anima tota tranquillitas. Sicut in paradiso nullus aestus aut frigus, ita in eius habitatore nulla ex cupiditate vel timore accedebat bonae voluntatis offensio. Nihil omnino triste, nihil erat inaniter laetum: gaudium verum perpetuabatur ex Deo, in quem flagrabat charitas de corde puro et conscientia bona et fide non ficta: atque inter se coniugum fida ex honesto amore societas, concors mentis corporisque vigilia, et mandati sine labore custodia. Non lassitudo fatigabat otiosum, non somnus praemebat invitum» ${ }^{132}$.

\section{LA CAÍDA DE LOS PRIMEROS PADRES.}

Esta situación paradisíaca se vino abajo con el pecado de Adán, antes incluso de que hubiese comenzado a gozar de ella. Ya hemos visto también la suerte que les esperaba, no sólo a los primeros hombres, sino también a sus descendientes si cometían el pecado ${ }^{133}$. Adán y Eva en efecto cometieron el pecado, se apartaron de Dios, y entonces les abandonó a la corrupción y a la muerte:

«Non enim deserta est (anima) ut desereret, sed ut desereretur, deseruit; ad malum quippe eius prior est volutas eius» ${ }^{134}$.

132 De Civ. Dei XIV, 26, PL 41, 434.

133 "Nec ignorabat Deus hominem peccaturum, et morti iam obnoxium morituros propagaturum, eoque progressuros pecicandi immanitate mortales, ut tutius atque pacatius inter se rationalis voluntatis expertes bestiae sui generis viverent, quarum ex aquis et terris plurium pullulavit exordium, quam homines, quorum genus ex uno est ad commendandam concordiam propagatum" (Ibid. XII, 22, PL 41, 372). Dios sabía con su ciencia infinita e infalibile que el hombre había de pecar. Sin embargo esta ciencia no anula la libertad del hombre, que pudo haber usado rectamente de su voluntad con la gracia divina que no le faltaba. Deil mismo modo Dios pudo evitar el pecado de los ángeles y el de los hombres, pero no quiso privarles de la libertad que les había concedido creándolos, para manifestar la superabundancia de su gracia. Cf. De Civ. Dei XIV, 27, PL 41, 435.

$1: 34$ Ibid. XIII, 15, PL 41, 387. 
El hombre, sin embargo, no desobedeció a Dios con un movimiento surgido exclusivamente de su voluntad, sino incitado por el demonio, envidioso de su felicidad y de su fidelidad a Dios. El ángel prevaricador, insinuándose bajo las apariencias de una serpiente, se acercó a Eva, y Eva engañada, comió del fruto prohibido. Comenzó por la parte más débil, la mujer, y después el varón, por amor a la esposa y no tanto por engaño, comió también del árbol de la ciencia del bien y del mal. Lo cual no quita gravedad a su pecado, pues pecó a ciencia y conciencia. Tal vez se equivocó en la apreciación de la gravedad de su acción, pero su disculpa, de que había sido incitado por la mujer, no fue aceptada por Dios. Por lo tanto, «aunque no fueron ambos engañados creyendo, con todo ambos fueron cogidos en pecado e implicados en las redes del demonio» ${ }^{135}$.

A alguno puede extrañar que una acción tan simple fuese considerada un pecado tan grande por Dios y tuviese tan graves consecuencias; a éstos responde San Agusín: no es la acción de comer lo que cuenta, sino el comer algo prohibido, es decir, la desobediencia a Dios:

«...si quis hoc movetur, ut dixi, non ideo debet existimare leve ac parvum illud fuisse commissum, quia in esca factum est, non quidem mala, nec noxia, nisi quia prohibita. Neque enim quidquam mali Deus in illo tantae felicitatis loco crearet atque plantaret. Sed obedientia commendata est in praecepto, quae virtus in creatura rationali mater quodammodo est omnium custosque virtutum: quandoquidem ita facta est, ut ei subditam esse sit utile; perniciosum autem suam, non eius a quo creata est, facere voluntatem. Hoc itaque de uno cibi genere non edendo, ubi aliorum tanta copia subiacebat, tam leve praeceptum ad observandum, tam breve ad memoria retinendum, ubi praesertim nondum voluntati cupiditas resistebat, quod de poena transgressionis postea subsecutum est, tanto maiore iniustitia violatum est, quanto faciliore posset observantia custodiri» ${ }^{136}$.

135 Ibid. XIV, 11, 2, PL 41, 420.

136 Ibid. XIV, 12, PL 41, 420. "Quisquis huiusmodi damnationem vel nimiam, vel iniustam putat, metiri profecto nescit quanta fuerit iniquitas in peccando, ubi tanta erat non peccandi facilitas. Sicut enim Abrahae non inmerito magna obedientia praedicatur, quia ut occideret filium, res difficillima est imperaita: ita in paradiso tanto maior inobedientia fuit, quanto id quod praejcepltum est, nullius difficultatis fuit. Et sicut obedientia secundi hominis eo praedicabilior, quo factus est obediens usque ad mortem: ita inobedientia primi hominis eo detestabilior, quo factus est inobediens usque ad mortem. Ubi magna est inobedientiae poena proposita, et res a Creatore facilis imperata, quisnam satis explicet, quantum malum sit, non obedire in re facili, et tantae potestatis imperio, et tanto terrenti supplicio?" (Ibid. XIV, 15, 1, PL 41, 423). 
Por la desobediencia la acción de comer del fruto prohibido adquiere una gravedad inesperada. Pero no sólo por esto; en realidad la desobediencia procedió de la soberbia, y ésta es la que en último término constituye el pecado de Adán, que quiso hacerse como Dios:

«In occulto autem mali esse coeperunt, ut in apertam inobedientiam laberentur. Non enim ad malum opus perveniretur, nisi praecessisset mala voluntas. Porro malae voluntatis initium quod potui esse nisi superbia? «Initium enim omnis peccati superbia est». Quid est autem superbia, nisi perversae celsitudinis appetitus? Perversa enim celsitudo est, deserto eo cui debet animus inhaerere principio, sibi quodammodo fieri atque esse principium. Hoc fit, cum sibi nimis placet» 137 .

Más grave que la desobediencia, que la transgresión del precepto divino, fue esta soberbia que originó tal acción, ese querer elevarse hasta Dios con sus propias fuerzas ${ }^{138}$.

De todo lo dicho aparece claramente que, según San Agustín, el pecado del paraíso fue un pecado de soberbia y de desobediencia, no un pecado sexual, que por otra parte es casi imposible, como se deduce del completo dominio voluntario de la sexualidad de que gozaban los primeros padres en el paraíso. Bien claramente dice San Agustín que el pecado de Adán consistió en querer ser Dios, en abandonar el bien inmutable para buscar su propia exaltación, en desobedecer al mandato divino ${ }^{139}$. La libido no fue causa, sino castigo del pecado, como veremos un poco más adelante.

137 Ibid. XIV, 13, 1, PL 41, 420. “Manifesto ergo apertoque peccato, ubi ifactum est quod Deus fieri prohibuerat, diabolus hominem non cepisset, nisi iam ille sibi ipsi placere coepisset. Hinc enim et delectavit quod dictum esit, Eritis sicut dii. Quod melius esse possent summo veroque principio cohaerendo per obedientiam, non suum sibi existendo principium per superbiam. Dii enim creati, non sua veritate, sed Dei veri participatione sunt dii" (Ibid. XIV, 13, 2, PL 41, 421).

138 Ibid. XIV, 14, PL 41, 422.

139 "Tamen et alios sumebant cibos praeter unam arborem, quae fuerat interdicta, non quia ipsa erat malum, sed propiter commendandum purae et simplicis obedientiae bonum, quae magna virtus est rationalis creaturae sub Creatore Domino constitutae. Nam ubi nullum malum tangebatur, profecto si prohibitum tangeretur, sola inobedientia peccabatur" (Ibid. XIII, 20, PL 41, 394). "Senserunt ergo novum motum inobedientis carnis suae, tanquam reciproca poena inobedientiae suae" (Ibid. XIII, 13, PL 41, 386). En este texto y en otros parecidos se han basado algunos para decir que San Agustín concibe el primer pecado como un pecado sexual. Pero es evidente que el desorden sexual de que habla es consecuencia del pecado, no causa del mismo. Cf. F. AsEnsio, iTradición sobre un pecado sexual en el paraíso?, "Gregorianum" 31 (1950) 35-62; J. DE BLIC, Le péché originel selon Saint Augustin, en "Recherches de Science 
LA MUERTE, PENA DEL PECADO.

Antes de entrar directamente en tema debemos ver, como hace San Agustín, las diversas clases de muerte que existen. San Agustín distingue la muerte del alma de la del cuerpo. Aunque el alma es inmortal, se dice que muere cuando es abandonada por Dios por haberle abandonado ella antes, así como el cuerpo muere cuando de él se aleja el alma. Cuando estas dos muertes se dan en un mismo sujeto tenemos la muerte total. A esta sigue la muerte segunda, cuando alma y cuerpo, después de la resurrección, serán arrojados al infierno. Se llama muerte primera la separación del alma y el cuerpo. En el caso de los pecadores es lo mismo que la muerte total; en el caso de los justos esta muerte del cuerpo será reparada con la resurrección y la gloria final, cuando el alma y el cuerpo gozarán eternamente de Dios ${ }^{140}$.

San Agustín se pregunta si la muerte es pena también de los justos, de los que han sido regenerados por la gracia de Cristo, recibida en el bautismo, y por qué. Evidentemente también ellos pasan por la muerte corporal, pues todos estábamos incluídos en Adán, en quien pecamos y en quien recibimos la pena de la muerte. Además si la fe en Cristo y su gracia nos librasen de la muerte, ¿no correríamos todos a bautizarnos para escapar de la muerte? Así la fe no sería genuina, no se creería por la esperanza del premio futuro, sino por la inmortalidad inmediata ${ }^{141}$. Por lo tanto los justos se ven libres de la muerte segunda y total, pero no de la muerte primera, en la cual su alma se ve desligada del cuerpo corruptible.

La muerte es una cosa mala, impuesta al género humano como pena del pecado. Sin embargo, a pesar de que es mala, los justos usan bien de ella y sacan abundante provecho espiritual, como se ve claramente en el caso de los mártires:

religieuse", 16 (1926) 97-119; 17 (1927) 414-433; 512-531; J. ClemenCE, Saint Augustin et le péché originel, en "Nouvelle Revue Théologique" 1948, 727-753; Athanase Sage, Le péché originel dans la pensée de Saint Augustin de 412 $\grave{a} 430$, en "Revue des Eitudes Augustiniennes" XV (1969) 75-112; CÉsAR VACA, Puntos para una psicología del pecado en La Ciudad de Dios, "La Ciudad de Dios:" 167 (1955) 269-282.

140 De Civ. Dei XIII, 2, PL 41, 377.

141 Ibid. XIII, 3-4, PL 41, 378-380. 
«Nunc vero maiore et mirabiliore gratia Salvatoris in usus iustitiae peccati poena conversa est. (...) Sic per ineffabilem Dei misericordiam, et ipsa poena vitiorum transit in arma virtutis, et fit iusti meritum etiam supplicium peccatoris. Tunc enim mors est acquisita peccando, nunc impletur iustitia moriendo. Verum hoc in sanctis martyribus, quibus alterutrum a persecutore proponitur, ut aut deserant fidem, aut sufferant mortem. Iusti enim malunt credendo perpeti, quod sunt primi iniqui non credendo perpessi. Nisi enim peccassent illi, non morerentur: peccabunt autem isti, nisi moriantur. Mortui sunt ergo illi, quia peccaverunt: non peccant isti, quia moriuntur. Factum est per illorum culpam, ut veniretur in poenam: fit per istorum poenam, ne veniantur in culpam: non quia mors bonum aliquod facta est, quae antea malum fuit; sed tantam Deus fidei praestitit gratiam, ut mors, quam vitae constat esse contrariam, instrumentum fieret per quod transiretur ad vitam» 142 .

Así como los pecadores usan mal de la ley, que es buena, así los santos usan bien de la muerte, que es mala ${ }^{143}$.

No obstante esto, no obstante que los justos usen bien de la muerte, no por eso deja de ser un mal, incluso para éstos. Y su maldad consiste en la separación del alma del cuerpo, en ese desgarrón, tan duro para la sensibilidad, de las dos partes que forman el compuesto humano:

«Quapropter, quod attinet ad corporis mortem, id est separationem animae a corpore, cum eam patiuntur qui morientes appellantur, nulli bona est. Habet enim asperum sensum et contra naturam vis ipsa qua utrumque divellitur, quod fuerat in vivente coniunctum atque consertum, quamdiu moratur, donec omnis adimatur sensus, qui ex ipso inerat animae carnisque complexu» 144 .

Por este sufrimiento que lleva consigo este desgarramiento del alma y el cuerpo, la muerte puede convertirse en medio para la remisión de los pecados y para la satisfacción de la pena, incluso en aquellos que no han sido bautizados:

142 Ibid. XIII, 4, PL 41, 379.

143 "Quia scilicet sicut lex non est malum, quando auget peccantium concupiscentiam; ita nec mors bonum est, quando auget patientium gloriam: cum vel illa pro iniquitate deseritur, et efficit praevaricatores; vel ista pro veritaite suscipitur, et efficit martiyres. Ac per hoc lex quidem bona est, quia prohibitio est peccati; mors autem mala, quia stipendium est peccati: sed quemadmodum iniusiti male utuntur non tantum malis, sed etiam bonis; ita iusti bene non tantum bonis, sed etiam malis. Hinc fit ut et mali male iege utantur quamvis sit lex bonum; et boni bene moriantur, quamvis sit mors malum" (Ibid. XIII, 5, PL 41, 380).

144 I!bid. XIII, 6, PL 41, 381. 
«Nam quicumque etiam non percepto regenerationis lavacro pro Christi confessione moriuntur, tantum eis valet ad dimittenda peccata, quantum si abluerentur sacro fonte baptismatis... Quid enim pretiosius quam mors, per quam fit ut et delicta omnia dimittantur, et merita cumulatius augeantur?» 145 .

Tienen más mérito los que prefieren morir antes que negar a Cristo, aun cuando no puedan bautizarse, que los que difieren su muerte para poder bautizarse. $\mathrm{Y}$ esto por el gran amor a Cristo que supone:

«Mors igitur pretiosa sanctorum, quibus cum tanta gratia est praemissa et praerogata mors Christi, ut ad eum acquirendum suam non cunctarentur impendere, in eos usus redactum esse monstravit, quod ad poenam peccantis antea fuerat constitutum, ut inde iustitiae fructus uberior nasceretur. Mors ergo non ideo bonum videri debet, quia in tantam utilitatem non vi sua, sed divina opitulatione conversa est; ut quae tunc metuenda proposita est, ne peccatum committeretur, nunc suscipienda proponatur, ut peccatum non committatur, commissumque deleatur, magnaeque victoriae debita iustitiae palma reddatur» ${ }^{146}$.

La muerte, en sí, repite San Agustín, es mala para todos. Los justos aceptan la muerte corporal para evitar la muerte segunda, eterna, la condenación del alma y del cuerpo al infierno. La muerte, mientras está en acto en los moribundos, es mala para todos. Una vez pasada, para los buenos es buena, porque sus almas gozan de Dios, y mala para los malos, cuyas almas padecen las penas debidas a sus pecados ${ }^{147}$.

145 Ibid. XIII, 7, PL 41, 381.

146 Ibid. XIII, 7. PL 41, 381

147 "Si enim diligentius consideramus, etiam cum quisque pro veritate fideliter et laudabiliter moritur, mors cavetur. Ideo quippe aliquid eius suscipitur, ne tota contingat, et secunda insuper, quae nunquam finiatur, accedat. Suscipitur enim animae a corpore separatio, ne Deo ab anima separato etiam ipsa separetur a corpore, ac sic totius hominis prima morte completa, secunda excipiat sempiiterna. Quocirca mors quidem, ut dixi cum eam morientes patiuntur, cumque in eis ut moriantur facit, nemini bona est, sed laudabiliter toleratur pro tenendo vel adipiscendo bono. Cum vero in ea sunt, qui iam montui nuncupantur, non absurde dicitur et malis mala, et bonis bona. In requie enim sunt animae piorum a corpore separatae; impiorum autem poenas luunt; donec istarum ad aeternam vitam, illarum vero ad aeternam mortem, quae secunda dicitur, corpora reviviscant" (Ibid. XIII, 8, PL 41, 382). "Convenienter itaque factum est, ut, quemadmodum id quod significat, non potest agendo, ita ipsum verbum declinari loquendo non possit. Agi tamen potest in adiutorio gratiae redempitoris nostri, ut saltem secundam mortem declinare possimus. Illa enim est gravior, et omnium malorum pessima, quae non fit separatione animae et corporis, sed in aeternam pocnam potius utriusque complexu. Ibi e contrario non erunt homines ante 
Si la muerte es un mal, como pena que es del pecado, la misma vida, que otra cosa no es sino una carrera hacia la muerte, se ha convertido también en una vida de penalidades en este valle de lágrimas ${ }^{148}$.

¿Qué clase de muerte conminó Dios a los primeros padres como pena del pecado? No sólo la primera, dice San Agustín, sino todas, la segunda y la total juntamente, el castigo del alma y el del cuerpo:

«Quando ergo dixit Deus primo illi homini, quem in paradiso constituerat, de cibo vetito, «Quacumque die ederitis ex eo, morte moriemini» (Gen. 2, 17): non tantum primae mortis partem priorem, ubi anima privatur Deo; nec tantum posteriorem, ubi corpus privatur anima; nec solum ipsam totam primam, ubi anima et a Deo et a corpore separata punitur: sed quidquid mortis est usque ad novissimam, quae secunda dicitur, qua est nulla posterior, comminatio illa complexa est» ${ }^{149}$.

Toda clase de muertes esperaban al hombre pecador, no sólo la separación del alma y del cuerpo:

«Etiamsi ergo hanc intelligamus Deum denuntiasse mortem, in eo quod ait, «Qua die ederitis ex illo, morte moriemini»; tamquam diceret, «Qua die me deserueritis per inobedientiam, deseram vos per iustitiam»: profecto in ea

mortem atque post mortem, sed semper in morte: ac per hoc nunquam viventes, nunquam mortui, sed sine fine morientes. Nunquam enim erit homini peius in morte quam ubi erit mors ipsa sine morte" (Ibid. XIII, 11, 2, PL 41, 385).

148 "Ex quo enim quisque in isto corpore morituro esse coeperit, nunquam in eo non agitur ut mors veniat. Hoc enim agiit eius mutabilitas toto tempore vitae huius (si tamen vita dicenda est), ut veniatur in mortem. Nemo quippe est qui non ei post annum sit quam ante annum fuit, et cras quam hodie, et hodie quam heri, et paulo post quam nunc, eit nunc quam paulo ante propinquior. Quoniam quidquid temporis vivitur, de spatio vivendi demitur; et quotidie fit minus minusque quod restat: ut omnino nihil sit aliud tempus vitae huius quam cursus ad mortem, in quo nemo vel paululum stare, vel aliquando tardius ire permitititur: sed omnes ungentur pari motu, nec diverso impelluntur accessu. Neque enim cui vita brevior fuit, celerius diem duxit, quam ille cui longior: sed cum aequaliter et aequalia momenta raperentur ambobus, alter habuit propius, alter remotius quo non impari velocitate ambo curreibant. Aliud est autem amplius viae peregisse, aliud tardius ambulasse. Qui ergo usque ad mortem productiora spatia temporis agit, non lentius pergit, sed plus itineris conficit. Porro si ex illo quisque incipit mori, hoc est esse in morte, ex quo in illo agi coeperit ipsa mors, id est, vitae detracitio; quia, cum detrahendo finita fuerit, post mortem iam erit, non in morte: profecto ex quo esse incipit in hoc corpore, in morte est" (Ibid. XIII, 10, PL 41, 383). Nos encontramos ante un capítulo de evidente sabor existencialista, que nos recuerda los análisis de la vida humana hechos por HeIDEGGer, SARTRE y otros existencialistas.

149 Ibid. XIII, 12 , PL 41, 386. 
morte etiam caeterae denuntiatae sunt, quae procul dubio fuerant secuturae» 150 .

Dios en su infinita misericordia libró a algunos elegidos de la muerte segunda, pero en justicia todos estábamos destinados a esta muerte, como pena de nuestro pecado ${ }^{151}$.

Algunos filósofos dicen que la separación del alma y el cuerpo no es una pena, sino una liberación del alma de la cárcel del cuerpo. San Agustín dice que, si bien nuestro cuerpo corruptible es oneroso al alma, no por eso deja de ser penosa la muerte. Y nuestro cuerpo es oneroso al alma como consecuencia del pecado, no por su naturaleza, que es buena. Además San Agustín utiliza un argumento «ad hominem»: si decís que los cuerpos son cárceles de las almas, ¿cómo admitís que los dioses inferiores, e incluso Júpiter, el Dios supremo, tienen cuerpos inmortales, siendo, no obstante felices? ${ }^{152}$.

LAS PASIONES Y EL DESORDEN DE LA CARNE, CASTIGO DEL PECADO.

La muerte entró en el mundo como pena del pecado. Pero no sólo esto. En realidad la muerte no es más que el acto final de toda una serie de miserias que el hombre padece en esta vida como conscuencia del pecado; o si se prefiere expresar esta idea a la inversa, podemos decir, con el mismo Agustín, que la vida no es más que una muerte prolongada.

Toda nuestra vida es una continua lucha entre las fuerzas desordenadas de la carne y del espíritu. Después del pecado, el hombre quedó desamparado de Dios, y por haberse rebelado contra $\mathrm{El}$, su carne se rebeló contra sí mismo, contra su espíritu ${ }^{153}$. Antes del

\footnotetext{
150 Ibid. XIII, 15, PL 41, 387. Cf. todo el capítulo.

151 "Ac per hoc a liberi arbitrii malo usu series huius calamitatis exorta est, quae humanum genus origine depravata, velut radice corrupta, usque ad secundae mortis exitium, quae non habet finem, solis eis exceptis qui per gratiam Dei liberantur, miseriarum connexione perducit" (Ibid. XIII, 14, PL 41, 386). "...ut ex his duabus mors illa prima, quae totius est hominis, compleretur quam secunda in ultimo sequitur, nisi homo per gratiam liberetur" (Ibid. XIII, 15, PL 41, 387). Cf. Ibid. XIII, 23, 1-3, PL 41, 395-398. "Mortuus spiritu volens, et compore moriturus invitus; desertor aeternae vitae, etiam aeterna, nisi gratia liberaret', morte damnatus" (Ibid. XIV, 15, 1, PL 41, 423).

152 Ibid. XIII, 16-18, PL 41, 387-391.

153 "Iam quippe anima libertate in perversum propria delectata, et Deo dedignata servire, pristino corporis servitio destituebatur: et quia superiorem Dominum suo arbitrio deseruerat, inferiorem famulum ad suum arbitrium non
} 
pecado el alma y el cuerpo vivían en armoniosa integridad. Pero una vez cometido el pecado, Dios entregó al hombre a la desobediencia de su carne y a las miserias de su cuerpo corruptible. No que estas cosas fueron causa del pecado, sino castigo del mismo, pues el mal procede de la voluntad:

\begin{abstract}
«...tamen aliter se habet fides nostra. Nam corruptio corporis, quae aggravat animam, non peccati primi est causa, sed poena; nec caro corruptibilis animam peccatricem, sed anima peccatrix fecit esse corruptibilem carnem. Ex qua corruptione carnis licet exsistant quaedam incitamenta vitiorum, et ipsa desideria vitiosa: non tamen omnia vitae iniquae vitia tribuenda sunt carni, ne ab his omnibus purgemus diabolum, qui non habet carnem. Etsi enim diabolus fornicator vel ebriosus, vel si quid huiusmodi mali est quod carnis pertinet voluptates, non potest dici, cum sit etiam talium peccatorum suasor et instigator occultus: est tamen maxime superbus atque invidus. Quae illum vitiositas sic obtinuit, ut propter hanc esset in carceribus caliginosi huius aeris aeterno supplicio destinatus. Haec autem vitia quae tenent in diabolo principatum, carni tribuit Apostolus, quam certum est diabolum non habere» 154 .
\end{abstract}

Con esto San Agustín quiere decir que no se ha de confundir la carne con el cuerpo. La carne, o bien el hombre carnal, es el hombre en cuanto enfrentado a Dios por su rebelión y su pecado ${ }^{155}$. El hombre espiritual, del mismo modo, no es el alma, por oposición al cuerpo, sino el hombre total en cuanto se opone a las fuerzas del pecado y trata de mantenerse unido a Dios. No podemos hacer una separación absoluta entre el alma y el cuerpo; en este aspecto que estamos tratando, la única división posible es la que surge entre el espíritu de Dios y el espíritu del hombre, entre el amor a Dios y el amor a sí mismo: De estos dos amores nace la distinción entre hombres espirituales y carnales, entre justos y pecadores, entre la ciudad de Dios y la del diablo. Pues tanto la carne como el espíritu, el cuerpo como el alma del hombre, fueron creados buenos, y tanto el uno como el otro colaboraron a la comisión del pecado original, $\mathrm{v}$ así ahora ambos sufren las consecuencias, siendo ambos causa de nuevos pecados ${ }^{156}$. El hombre está dividido y lucha contra sí mismo,

\footnotetext{
tenebat: nec omni modo habebat subditam carnem, sicut semper habere potuisset, si Deo subdita ipsa mansisset" (Ibid. XIII, 13, PL 41, 386).

154 Ibid'. XIV, 3,2 , PL $41,406$.

155 Ibi.d. XIV, 4, 1-2, PL 41, 407.

156: Ibid. XIV, 5, PL 41, 408 .
} 
no sólo el cuerpo contra el alma, sino todo el hombre contra todo el hombre, el hombre que quiere servir a Dios contra el que quiere mantenerse en la rebelión.

En este estado de postración causado por el pecado surgen las pasiones, el deseo y el temor, la alegría y la tristeza, muestra clara del desorden y desgobierno causado en el hombre por su desobediencia a Dios. En realidad, dice San Agustín, estas pasiones no son más que diversas formas de querer o de amar, y por lo tanto serán rectas o pecaminosas según sea ese amor que esencialmente las constituye:

«Recta itaque voluntas est bonus amor, et voluntas perversa malus amor. Amor ergo inhians habere quod amatur, cupiditas est; id autem habens eoque fruens, laetitia est; fugiens quod ei adversatur, timor est; idque si acciderit sentiens, tristitia est. Proinde mala sunt ista, si malus est amor; bona, si bonus» 157 .

Pero con frecuencia vemos que estas pasiones se rebelan contra la voluntad, que no se someten al amor casto y humilde de Dios, y esto es claramente efecto del pecado. En el paraíso existían el gozo y la alegría, pues era aquel un estado de felicidad sin ningún inconveniente, pero una santa alegría, fruto de la obediencia a Dios y de la paz interna y externa que nacía de la sumisión amorosa de Adán y Eva a Dios; estas dos pasiones existirán también en la vida bienaventurada, sublimadas y purificadas de todos los lastres de esta vida pecadora. El temor y la tristeza, ni existieron en el paraíso, como ya hemos visto, ni existirán en el cielo, donde los justos gozarán de Dios por toda la eternidad, seguros de su felicidad y sin ningún miedo a perderla.

157 Ibid. XIV, 7, 2, PL 41, 410. "Interest autem qualis sit voluntas hominis: quia si perversa est, perversos habebit hos motus; si autem recta est, non solum inculpabiles, verum etiam laudabiles erunt. Volunitas est quippe in omnibus: imo omnes nihil aliud quam volunitates sunt. Nam quid est cupiditas et laetitia, nisi voluntas in eorum consensionem quae volumus? et quid est metus atque tristitia nisi voluntas in dissensionem ab his quae nolumus? Sed cum consentimus appetendo ea quae volumus, cupiditas; cum autem consentimus fruendo his quae volumus, laetitia vocatur. Itemique cum dissentimus ab eo quod accidere nolumus, talis voluntas metus est; cum autem dissentimus ab eo guod nolentibus accidit talis voluntas tristitia est" (Ilbid. XIV, 6, PL 41, 409). En realidad todos los nueve primeros capítulos del libro XIV son como un único argumento prolongado, con diversas variaciones, dirigido a probar que las pasiones son; en sí mismas, indiferentes, y que su bondad o malicia depende del uso que la voluntad haga de ellas, 
El hombre, abandonando a Dios por el pecado, recibió como castigo de ese pecado la desobediencia de sí mismo contra sí mismo: el cuerpo se rebela contra el alma, que no puede sujetar la carne; el alma no es capaz de hacer lo que quiere con el cuerpo; y el alma se rebela contra el alma, y el cuerpo contra el cuerpo: en definitiva, el hombre está en lucha continua contra sí mismo ${ }^{158}$.

La prueba más palpable de este desorden, de esta rebelión, es la libido, el apetito insaciable de placeres sexuales, en contra de la voluntad, que se ve completamente incapaz de ejercer su dominio sobre estas facultades sexuales. Es cierto, dice San Agustín, que existen varias clases de libido: libido de venganza, llamada ira, libido de dinero o avaricia, libido de gloria o jactancia, etc., todas causadas por el pecado. Pero cuando hablamos de libido sin más, nos referimos generalmente a la que excita las partes sexuales del cuerpo, los órganos genitales.

La libido sexual es tan fuerte que en su colmo, por la gran intensidad del placer corporal, llega hasta ofuscar la razón ${ }^{159}$. Esta libido, ya lo hemos visto, no existía en el paraíso: surgió después del pecado como castigo del mismo, privando al hombre del control de sí mismo. Signo de esta libido es el pudor de los primeros padres al constatar su desnudez. Antes no se avergonzaban de estar desnudos, porque les cubría la gracia divina y sus miembros estaban sometidos a la voluntad; sólo después del pecado nace este rubor, dando a entender la rebelión que se ha obrado en su cuerpo como consecuencia de su rebelión contra Dios ${ }^{160}$. Este pudor se extiende a todos los descendientes de Adán y Eva y se manifiesta en el secreto y retiro con que se realiza el acto conyugal; no sólo la unión carnal deshonesta, que busca el placer por el placer, se esconde de

158 "Denique, ut breviter dicaitur, in illius peccati poena, quid inobedientiae nisi inobedientia retributa est? Nam quae hominis est alia miseria, nisi adversus eum ipsum inobedientia eius ipsius, ut quoniam noluit quod potuit, quod non potest velit?" (Ibid. XIV, 15, 2, PL 41. 423). Cf. todo este capítulo.

159 "Cum igitur sinit multarum libidines rerum, tamen cum libido dicitur, neque cuius rei libido sit additur, non fere assolet animo occurrere nisi illa, qua obscenae corporis partes excitantur. Haec autem sibi non solum totum, nec solum extrinsecus, verum etiam intrinsecus vindicat, toitumque commovet hominem animi simul affectu cum carnis appetitu coniuncto atque permixto, ut ea voluptas sequatur, qua maior in corporis voluptatibus nulla est: ita momento ipso temporis, quod ad eius pervenitur extremum, pene omnis acies et quasi vigilia cogitationis obruatur" (Ibid: XIV, 16, PL 41, 422).

160 Ibid. XIV, 17, PL 41, 425. 
las miradas indiscretas, sino también el mismo acto matrimonial realizado en vista de la procreación de los hijos busca el apartamiento y la soledad absoluta ${ }^{161}$. Y esto en contra de los cínicos, que decían que, siendo legítima la unión carnal de los esposos, no debería causar vergüenza realizarla en público. El sentido común ha prevalecido sobre esta teoría, mostrando claramente lo profundamente grabado que está en el hombre este pudor ${ }^{162}$.

La libido surgió, pues, como pena del pecado, y lo mismo sucede con este pudor que recatadamente cubre las manifestaciones de esta libido. Pero no por eso se ha de decir que la unión matrimonial es mala: la bendición del matrimonio fue dada a los primeros padres antes del pecado, para mostrar que la procreación de los hijos es un don de Dios, gloria del matrimonio, no pena del pecado. La pena del pecado no es la unión carnal en sí, sino los ardores desordenados de la libido que acompañan a la unión carnal, ardores que no se daban en el paraíso ${ }^{163}$.

161 Ibid. XIV, 18, PL 41, 426. ¿Por qué, se pregunta San Agustín, los movimientos de la libido se cubren con el pudor y el recato, y no pasa lo mismo con las otras pasiones, como la ira o la avaricia? Porque en los demás movimientos desoridenados la voluntad sigue manteniendo, en un cierto sentido, su dominio sobre las partes del cuerpo, cosa que no sucede con la libido. Esta incarpacidad absoluta de la voluntad de gobernar los órganos genitales, que se mueven exclusivamente por la excitación de la libido, es lo que avergüenza al hombre y lo que causa el pudor. Cf. De Civ. Dei XIV, 19, PL 427. "Verumtamen haec libido, de qua nunc disserimus, eo magis erubescenda exsistit, quod animus in ea nec sibi efficaciter imperat, ut omnino non libeat; nec omnimodo corpori, ut pudenda membra volunitas potius quam libido commoveat: quod si ita esset, pudenda non essent. Nunc vero pudet animum resisti sibi a corpore, quod ei natura inferiore subiectum est" (Ibid. XIV, 23, 2, PL 41, 431).

162 "Pudet igitur huius libidinis humanam sine ulla dubitatione naturam, et merito pudet. In eius quippe inobedientia, quae genitalia corporis membra solis suis moitibus subdidit, et poitestati eripuit voluntatis, satis ostenditur quid sit hominis illi primae inobedientiae retributum: quod in ea maxime parte oportuit apparere, qua generatur ipsa natura, quae illo primo et magno in deterius est mutata peccato: a cuius nexu nullus eruitur, nisi id quod, cum omnes in uno essent, in communem perniciem perpetratum est, et Dei iustitia vindicatum, Dei gratia in singulis expietur" (Ibid. XIV, 20, PL 41, 428).

163 "Post peccatum quippe orta est haec libido; post peccatum eam natura non impudens, amissa potestate cui corpus ex omni parte serviebat, sensit, attendit, erubuit, operuit. Illa vero benedictio nuptiarum, ut coniugati crescerent, et multiplicarentur, et implerent terram, quamvis et in delinquentibus manserit; tamen antequam delinquerent data est, ut cognosceretur procreationem filiorum ad gloriam connubii, non ad poenam pertinere peccati" (Ibid. XIV, 21, PL 41, 428). Cf. también el capítulo siguiente. Clara alusión a la doctrina maniquea del matrimonio y de las relaciones conyugales. Sobre este tema de la sexualidad puede consultarse J. MORÁN, Sexualidad, humanización y pecado original. A propósito del libro XIV de Civitate Dei, en "Archivo Teológico Agustiniano" 1 (1966) 215-244. Sobre toda la doctrina antropológica de la La Ciudad de Dios, cf. Eloy D. Carretero, Antropología teológica de La Ciudad de Dios, en "La 
En resumen, el hombre fue abandonado por Dios, fue abandonado a sí mismo por haber él abandonado a Dios, y en este abandono encuentra su mayor castigo, al no poder ejercer un dominio ordenador sobre sus facultades y tener que sufrir la lucha despiadada de sí mismo contra sí mismo ${ }^{164}$.

Hemos dicho que el estado de felicidad del paraíso se habría transmitido a todos los descendientes de Adán y Eva si éstos no hubiesen pecado. Igualmente debemos decir ahora a la inversa que este pecado y sus consecuencias han pasado a todos los hombres, descendientes de aquella primera pareja.

La muerte y la corrupción, las pasiones y la libido son patrimonio común de la humanidad, heredado gracias a aquella primera desobediencia. La muerte de tal manera se apoderó del género humano que todos estábamos condenados a la muerte segunda y total, de la cual sólo algunos son salvados por los méritos redentores del Mediador, Cristo ${ }^{165}$.

Del mismo modo, las pasiones y la libido sexual, con todos los desórdenes del hombre en lucha consigo mismo, se han ido propagando a todos los descendientes de Adán y Eva como una viscosidad pegajosa de la cual el hombre es incapaz de liberarse por sí mismo ${ }^{166}$.

Ciudad de Dios" 167 (1965) 193-268: artículo amplio y bien desarrollado, que presenta todos los temas tratados por San Agustín, desde la creación y pecado del hombre hasta su redención y salvación.

164 De Civ. Dei XIV, 24, 2, PL 41, 433.

165 "Sed eosdem primos peccatores ita fuisse morte mulctatos, ut etiam quidquid de eorum stirpe esset exortum, eidem poenae teneretur obnoxium" (Ibid. XIII, 3, PL 41, 378). 'Cf'. la continuación de este texto, hasta el final del capítulo. "D€us enim creavit hominem rectum, naturarum auctor, non utique vitiorum: sed sponte depravatus iusteque damnatus, depravatos damnatosque generavit. Omnes enim fuimus in illo uno, quando omnes fuimus ille unus, qui per feminam lapsus est in peccatum, quae de illo facta est ante peccatum. Nondum erat nobis singillatim creata et distributa forma, in qua singuli viveremus; sed iam natura erat seminalis, ex qua propagaremur; qua scilicet propter peccatum vitiata, et vinculo mortis obstricta, iusteque damnata, non alterius conditionis homo ex homine nasceretur" (Ibid. XIII, 14, PL 41, 386). "Neque hoc genus fuisse in singulis quibusaue moriturum, nisi duo primi quorum creatus est unus ex nullo, altera ex illo, id inobedientia meruissent: a quibus admissum est tam grande peccatum, ut in deterius eo natura mutaretur humana, etiam in posteros obligatione peccati et mortis neccesitate transmissa. Mortis autem regnum in homines usque adeo dominatum est, ut omnes in secundam quoque mortem, cuius nullus est finis, poena debita, praecipites ageret, nisi inde quosdam indebita Dei gratia liberaret" (Ibid. XIV, 1, PL 41, 403).

166 "Tunc engo coepit caro concupiscere adversus spiritum: cum qua controversia nati sumus, trahentes originem mortis, et in membris nostris vitiataque natura contentionem eius sive victoriam de prima praevaricatione gestantes" 


\section{DESARROLLO Y CONSUMACIÓN DE LAS DOS CIUDADES.}

«Fecerunt itaque civitates duas amores duo; terrenam scilicet amor sui usque ad contemptum Dei; caelestem vero amor Dei usque ad contemptum sui» 167 .

Hemos estudiado en los libros XI-XIV de La Ciudad de Dios el nacimiento de las dos ciudades en el tiempo, el punto de origen de las dos sociedades que se enfrentarán a lo largo de toda la historia, hasta el fin de los tiempos. Ahora, para terminar este trabajo, hagamos una breve alusión al desarrollo y a la consumación final de estas dos ciudades, resumiendo brevemente el contenido de los libros siguientes de esta gran obra de San Agustín.

En los libros XV-XVIII San Agustín presenta el desarrollo de las dos ciudades en la tierra. En los hijos de Adán y Eva, es decir, en Caín y Abel, encontramos por primera vez las dos ciudades frente a frente; este enfrentamiento durará a lo largo de toda la historia, aunque a veces puede darse una peligrosa y engañosa paz entre ambas.

El pueblo de Israel representa la ciudad de Dios en el Antiguo Testamento, así como la Iglesia, de la cual el pueblo elegido es signo profético, la representa en el Nuevo. Esto no quiere decir que todos los israelitas y todos los cristianos formen parte de esta santa ciudad, así como tampoco todos los gentiles o paganos pertenecen a la ciudad terrena. Mientras peregrinamos en esta tierra, ambas sociedades están confundidas y no existe entre ellas una clara línea divisoria, que sólo aparecerá cuando llegue la separación definitiva en el día del juicio final.

La ciudad santa está edificada sobre Cristo, piedra angular de la misma y centro de toda la historia. Sin la mediación redentora de Cristo Jesús no existiría la ciudad de Dios: todos los hombres, por el pecado, habían quedado sometidos al demonio, condenados a la muerte eterna; sólo en virtud de los méritos de Cristo Dios rescata a algunos de esa «massa damnata», formando con ellos la sociedad

(Ibid. XIII, 13, UL 41, 386). "Induimus autem imaginem terreni hominis propagatione praevaricationis eit mortis, quam nobis intulit generatio" (Ibid. XIII, 23, 3, PL 41, 398).

${ }_{167}$ De Civ. Dei XIV, 28, PL 41, 436. 
de los hijos de Dios. La cruz de Cristo, centro de la historia, abarca con sus brazos extendidos todo el transcurso del tiempo, tanto hacia adelante, hasta la consumación final, como hacia atrás, hasta los orígenes del mismo en la creación. Los justos del Antiguo Testamento son justos en virtud de los méritos previstos de Cristo, y los santos de la nueva alianza son santos en virtud de la obra redentora, ya realizada, del único Mediador, Cristo Jesús. El Nuevo Testamento está escondido en el Antiguo, y el Antiguo se manifiesta con todo su esplendor en el Nuevo, centrados ambos en la encarnación del Verbo.

En el libro XIX San Agustín estudia genéricamente los fines de las dos ciudades. Es un libro bellísimo, en el que el Santo hace un profundo análisis de las nociones de justicia, paz y felicidad, mostrando la felicidad que se puede gozar en esta vida y la que nos espera en la eterna.

El libro XX está dedicado al juicio final, o separación definitiva de las dos ciudades, aduciendo testimonios del Antiguo y del Nuevo Testamento para ilustrar las particularidades de tal juicio. Después del juicio cada sociedad recibirá el justo merecido de sus obras: la ciudad terrena, las penas eternas del infierno (libro XXI), la ciudad de Dios, el cielo (libro XXII), la paz sin fin de la nueva Jerusalén, la felicidad eterna de la visión divina, el descanso perpetuo del eterno sábado:

«Ibi vacabimus et videbimus; videbimus, et amabimus; amabimus et laúdabimus» 168

168 Ibid. XXII, 30, 5, PL 41, 804.

CÁNDIDo TEJERINA 